\title{
Water-Gas Shift Catalysis over Transition Metals Supported on Molybdenum Carbide
}

Kaiwalya D. Sabnis ${ }^{1, \S}$, Yanran Cui ${ }^{1}$, M. Cem Akatay, ${ }^{2, \#}$, Mayank Shekhar ${ }^{1, \mathbb{I}}$, Wen-Sheng Lee ${ }^{1, £}$, Jeffrey T. Miller ${ }^{1,3}$, W. Nicholas Delgass ${ }^{1}$ and Fabio H. Ribeiro ${ }^{1 *}$

${ }^{1}$ School of Chemical Engineering, Purdue University, West Lafayette, IN 47907 (USA)

${ }^{2}$ School of Materials Engineering, Purdue University, West Lafayette, IN 47907 (USA)

${ }^{3}$ Chemical Science and Engineering Division, Argonne National Laboratory, 9700 S. Cass Ave., Argonne, IL 60439 (USA)

\section{Author Information}

*Corresponding Author

School of Chemical Engineering, Purdue University, 480 Stadium Mall Drive, West Lafayette,

IN 47907-2100, USA. Tel: 765-494-7799. E-mail: fabio@ purdue.edu

Current addresses: ${ }^{\S}$ SABIC Technology Center, Sugar Land, TX 77478 (USA), ${ }^{\text {UOP LLC, Des }}$

Plaines, IL 60016 (USA), ${ }^{\mathbb{T}}$ ExxonMobil Chemical Company, Baytown, TX 77520 (USA), ${ }^{\mathfrak{f}}$ The

Dow Chemical Company, Core Research and Development, Midland, MI 48674(USA) 


\begin{abstract}
We report here that WGS rates per total surface area at $120^{\circ} \mathrm{C}, 7 \% \mathrm{CO}, 22 \% \mathrm{H}_{2} \mathrm{O}, 8.5 \% \mathrm{CO}_{2}$, $37 \% \mathrm{H}_{2}$ for $\mathrm{Pt}, \mathrm{Au}, \mathrm{Pd}$ and $\mathrm{Ni}$ supported over $\mathrm{Mo}_{2} \mathrm{C}$ were 4 to 8 times higher than those of the commercial $\mathrm{Cu} / \mathrm{ZnO} / \mathrm{Al}_{2} \mathrm{O}_{3}$ catalyst. In coherence with previous literature, the WGS rate per total moles of Pt over $\mathrm{Pt} / \mathrm{Mo}_{2} \mathrm{C}$ at $120^{\circ} \mathrm{C}$ has been shown to be higher than on any $\mathrm{Pt} / \mathrm{Metal}$ oxide catalysts. We have made use of systematic changes in the apparent kinetic parameters with various admetals (decrease in apparent $\mathrm{CO}$ order, apparent activation energy and increase in apparent $\mathrm{H}_{2} \mathrm{O}$ order compared to unpromoted $\mathrm{Mo}_{2} \mathrm{C}$ ) to conclude that the function of the ratepromoting admetals is to enhance the relative surface concentration of the adsorbed $\mathrm{CO}$, thereby leading to a promotion in the WGS rate per total surface area of the catalyst. Temperature programmed desorption of $\mathrm{CO}$ was used to show that the $\mathrm{CO}$ adsorption properties of $\mathrm{Mo}_{2} \mathrm{C}$ were modified by the various admetals by creating new metallic sites. In situ X-ray absorption on Pt and Au and STEM-EELS experiments showed that the supported Au nanoparticles over $\mathrm{Mo}_{2} \mathrm{C}$ decrease in average particle size from $\sim 9 \mathrm{~nm}$ to $3 \mathrm{~nm}$ after a $600^{\circ} \mathrm{C}$ carburization pretreatment. $\mathrm{Pt}$ was also shown to have assumed a stable structure at $600^{\circ} \mathrm{C}$ in the form of a Pt-Mo alloy. We suggest that $\mathrm{Mo}_{2} \mathrm{C}$ can be used to synthesize thermally robust supported metal catalysts.
\end{abstract}

\title{
Keywords
}

Molybdenum carbide; Water-gas shift; In situ X-ray absorption 


\section{Introduction}

Transition metal carbides (TMCs) such as $\mathrm{Mo}_{2} \mathrm{C}, \mathrm{WC}$, and $\mathrm{TiC}$ are formed by the incorporation of carbon atoms into the metal lattice. These materials have been shown to display intriguing catalytic properties. In one of the early observations of the catalytic activity of molybdenum carbide $\left(\mathrm{Mo}_{2} \mathrm{C}\right)$, Sinfelt and Yates [1] reported that during the process of ethane hydrogenolysis, the carburization of the molybdenum catalyst led to an increase of the reaction rate over time, and the formation of the molybdenum carbide was confirmed by X-ray diffraction. Numerous studies have shown that carbides of molybdenum and tungsten exhibit catalytic activities for several chemical reactions, viz. ammonia synthesis [2], carbon monoxide hydrogenation [3], methane reforming [4], and hydrodesulphurization [5]. The turnover rates for such reactions under reducing environments were equal to or greater than those on oxide supported metals such as $\mathrm{Pt}, \mathrm{Pd}$ and $\mathrm{Ru}$, and these materials were deemed to be cheaper replacements for the noble metal catalysts.

Many investigations followed. Patt et al. [6] studied the water-gas shift (WGS) reaction (CO + $\mathrm{H}_{2} \mathrm{O} \rightarrow \mathrm{CO}_{2}+\mathrm{H}_{2}$ ) over unsupported $\mathrm{Mo}_{2} \mathrm{C}$ and reported that the WGS reaction rates normalized by the amount (mass or surface area) of catalyst for $\mathrm{Mo}_{2} \mathrm{C}$ were comparable to those for the commercially used low temperature WGS catalyst, $\mathrm{Cu} / \mathrm{ZnO} / \mathrm{Al}_{2} \mathrm{O}_{3}$. Schweitzer et al. [7] used high surface area $\mathrm{Mo}_{2} \mathrm{C}$ as a supporting material for Pt nanoparticles to study WGS catalysis. It was shown that the WGS reaction rate normalized by total moles of Pt was higher compared to the most active oxide supported $\mathrm{Pt}$ catalysts such as $\mathrm{Pt} / \mathrm{CeO}_{2}$ and $\mathrm{Pt} / \mathrm{TiO}_{2}$. Also, the WGS rate per gram of catalyst for $\mathrm{Pt} / \mathrm{Mo}_{2} \mathrm{C}$ at $240^{\circ} \mathrm{C}$ was shown to be $4-5$ times higher than that of the unsupported $\mathrm{Mo}_{2} \mathrm{C}$. This study has laid the groundwork for the potential application of $\mathrm{Mo}_{2} \mathrm{C}$ as 
a support for making WGS catalysts with reaction rates per mole of noble metal higher than for the known noble metal catalysts.

In light of the work performed by Schweitzer et al. [7], we have explored the modifications in the WGS kinetics by addition of various transition metals to unsupported $\mathrm{Mo}_{2} \mathrm{C}$ with the objective of understanding the role of the admetals for promotion of the WGS rates. To gain insights into the high WGS rates over $\mathrm{Mo}_{2} \mathrm{C}$ and metals supported over $\mathrm{Mo}_{2} \mathrm{C}$, we have performed kinetic and spectroscopic investigation of several Metal/ $\mathrm{Mo}_{2} \mathrm{C}$ systems. Passivated, unsupported $\mathrm{Mo}_{2} \mathrm{C}$, synthesized via temperature programmed carburization in presence of a $\mathrm{CH}_{4} / \mathrm{H}_{2}$ mixture, was used as a support for making supported $\mathrm{Pt}, \mathrm{Pd}, \mathrm{Au}, \mathrm{Ni}, \mathrm{Cu}$ and $\mathrm{Ag}$ catalysts. Variation in the WGS reaction orders with admetals was studied and the role of the rate-promoting admetals is suggested to be the creation of alternative sites for $\mathrm{CO}$ activation, thereby increasing the availability of active CO. In coherence with the study by Schweitzer et al. [7], the superiority of the Metal/ $/ \mathrm{Mo}_{2} \mathrm{C}$ systems over the oxide supported catalysts has been confirmed. We have performed in situ X-ray absorption spectroscopy (XAS) to observe the working state of the catalysts during WGS reaction. Additionally, high resolution Scanning Transmission Electron Microscopy (STEM) microscopy combined with Electron Energy Loss Spectroscopy (EELS) was used to understand the morphology and qualitatively determine the composition of the supported metal particles. From the kinetics and structures of the catalyst a bifunctional active site for WGS is proposed.

\section{Experimental Methods}

\subsection{Catalyst Preparation}


The unsupported $\mathrm{Mo}_{2} \mathrm{C}$ was synthesized by temperature programmed carburization of an ammonium heptamolybdate precursor $\left((\mathrm{NH} 4)_{6} \mathrm{Mo}_{7} \mathrm{O}_{24} \cdot 4 \mathrm{H}_{2} \mathrm{O} ; 81-83 \%\right.$ as $\left.\mathrm{MoO}_{3}\right)$ from Alfa Aesar in a fixed bed reactor system with 0.5 grams of the precursor loaded in a quartz reactor tube over a quartz wool plug. The precursor was exposed to pure $\mathrm{H}_{2}(75 \mathrm{sccm})$, and the temperature was ramped to $350-370^{\circ} \mathrm{C}$ at $4^{\circ} \mathrm{C} \min ^{-1}$ and then held at that temperature for $10 \mathrm{~h}$. The temperature was further ramped to $600^{\circ} \mathrm{C}$ at $3^{\circ} \mathrm{C} \min ^{-1}$ after the gas was switched to a $15 \%$ $\mathrm{CH}_{4} / \mathrm{H}_{2}(75 \mathrm{sccm})$ mixture. The reactor was maintained at this temperature for 3.5 to $4 \mathrm{~h}$. It was then cooled to RT under the flow of Ar, and then the catalyst was passivated in a flow of $1 \%$ $\mathrm{O}_{2} / \mathrm{Ar}$. The oxygen concentration in the passivation mixture was progressively increased to $20 \%$ and the $\mathrm{Mo}_{2} \mathrm{C}$ support was ultimately exposed to air. Passivation was performed in order to avoid the spontaneous combustion of the freshly synthesized $\mathrm{Mo}_{2} \mathrm{C}$ upon exposure to the ambient air. The passivated $\mathrm{Mo}_{2} \mathrm{C}$ was used as a support for the synthesis of Metal/ $\mathrm{Mo}_{2} \mathrm{C}$ catalysts.

$\mathrm{Au} / \mathrm{Mo}_{2} \mathrm{C}$ was prepared using the deposition precipitation method. Chloroauric acid $\left(\mathrm{HAuCl}_{4} \cdot 3 \mathrm{H}_{2} \mathrm{O}\right.$, Sigma) was added to deionized water along with the support material. An appropriate amount of $1 \mathrm{~N} \mathrm{Na}_{2} \mathrm{CO}_{3}$ solution was added drop-wise to maintain a $\mathrm{pH}$ of 2.6 for 6 hours of stirring. Additional $\mathrm{Na}_{2} \mathrm{CO}_{3}$ was then added to bring the $\mathrm{pH}$ near 6.6 and the solution was stirred for another 4 hours. The mixture was then centrifuged, washed and dried. Atomic absorption spectroscopy was performed on each sample using an AAS, Perkin-Elmer AAnalyst 300 instrument. Prior to AAS measurements, the catalysts were digested in $2 \mathrm{~mL} / 1 \mathrm{~mL} / 100 \mathrm{mg}=$ aqua regia/HF/catalyst in a Nalgene ${ }^{\circledR}$ amber high-density polyethylene bottle for at least 3 days, and this solution was then diluted to the desired concentration for the AAS measurement. Concentrations of Au were determined by comparing results to those of known standards. 
Incipient wetness impregnation (IWI) was used for the preparation of $\mathrm{Pt}, \mathrm{Pd}, \mathrm{Ni}, \mathrm{Cu}$ and $\mathrm{Ag}$ supported on passivated $\mathrm{Mo}_{2} \mathrm{C}$. The precursors used were aqueous solutions containing appropriate amounts of Chloroplatinic acid $\left(\mathrm{H}_{2} \mathrm{PtCl}_{6} \cdot 6 \mathrm{H}_{2} \mathrm{O}\right.$, Sigma), Tetrammonium palladium (II)nitrate $\left(\mathrm{Pd}\left(\mathrm{NH}_{3}\right)_{4}\left(\mathrm{NO}_{3}\right)_{2}\right.$, Alfa Aesar), Nickel nitrate $\left(\mathrm{Ni}\left(\mathrm{NO}_{3}\right)_{2} \cdot 6 \mathrm{H}_{2} \mathrm{O}\right.$, Sigma), Copper nitrate $\left(\mathrm{Cu}\left(\mathrm{NO}_{3}\right) \cdot 3 \mathrm{H}_{2} \mathrm{O}\right.$, Alfa Aesar) and Silver nitrate $\left(\mathrm{AgNO}_{3}\right.$, Alfa Aesar) for $\mathrm{Pt}, \mathrm{Pd}, \mathrm{Ni}, \mathrm{Cu}$ and $\mathrm{Ag}$ respectively. The solutions were added drop-wise to the solid catalyst while it was stirred to enhance the mixing. The catalysts were then dried overnight at room temperature and reduced in the presence of pure $\mathrm{H}_{2}$ at $450^{\circ} \mathrm{C}$ for 3 hours and passivated using the method mentioned above. All the metal loadings were kept between 1.5 and $2 \mathrm{wt} \%$. The $\mathrm{Cu} / \mathrm{Zn} / \mathrm{Al}_{2} \mathrm{O}_{3}$ catalyst was obtained from Süd-Chemie in form of pellets. The pellets were crushed and sieved to size between 125 to 250 microns before being loaded into the reactor.

\subsection{WGS kinetic measurements}

Our lab is equipped with a fully automated setup of four parallel plug flow reactors, a detailed description of which can be found elsewhere [8]. The WGS reaction rates were measured under differential conditions, i.e. CO conversion was kept below $10 \%$ and the products of the WGS reaction $\left(\mathrm{CO}_{2}\right.$ and $\left.\mathrm{H}_{2}\right)$ were also co-fed. The appropriate amount of each catalyst was loaded so that the WGS kinetics could be measured at $120^{\circ} \mathrm{C}$ for all the samples. Since the catalysts were prepared over the passivated $\mathrm{Mo}_{2} \mathrm{C}$, prior to the kinetic measurement, each catalyst was subjected to temperature programmed carburization up to $600^{\circ} \mathrm{C}$ at $3^{\circ} \mathrm{C} \mathrm{min}^{-1}$ to bring the carbide surface back to its native form by the removal of oxygen from the surface. After this pretreatment, the reactors were cooled under Ar to $120^{\circ} \mathrm{C}$ and were exposed to the WGS reaction mixture (standard conditions, $7 \% \mathrm{CO}, 22 \% \mathrm{H}_{2} \mathrm{O}, 8.5 \% \mathrm{CO}_{2}, 37 \% \mathrm{H}_{2}$, and balance Ar) with a flow rate of $75.4 \mathrm{sccm}$. The $\mathrm{Cu} / \mathrm{ZnO} / \mathrm{Al}_{2} \mathrm{O}_{3}$ catalyst was reduced using a previously reported 
procedure [9]. In $5 \% \mathrm{H}_{2} / \mathrm{Ar}$, the temperature was increased to $150^{\circ} \mathrm{C}$ at $3{ }^{\circ} \mathrm{C} \min ^{-1}$ and from $150^{\circ} \mathrm{C}$ to $200^{\circ} \mathrm{C}$ at $0.17^{\circ} \mathrm{C} \min ^{-1}$ and was tested at $140^{\circ} \mathrm{C}$. The catalysts were stabilized for a period of $\sim 20$ hours, which was enough for the initial deactivation of approximately $20-25 \%$ to occur and a stable CO conversion value to be reached. The apparent reaction orders were then measured over the stabilized catalysts by varying the partial pressures of one component at a time over the range of $4-21 \% \mathrm{CO}, 5-25 \% \mathrm{CO}_{2}, 11-34 \% \mathrm{H}_{2} \mathrm{O}$, and $14-55 \% \mathrm{H}_{2}$. To determine the apparent activation energy, the temperature was varied from 110 to $140^{\circ} \mathrm{C}$, with the concentrations maintained at standard conditions. After the measurements were complete, the catalysts were passivated at room temperature.

\subsection{Catalyst Characterization}

The bulk structures of the $\mathrm{Mo}_{2} \mathrm{C}$ and $\mathrm{Metal} / \mathrm{Mo}_{2} \mathrm{C}$ catalysts were determined by $\mathrm{X}$-ray diffraction (XRD) using a Scintag X2 diffractometer with $\mathrm{Cu} \mathrm{K} \alpha$ radiation. Samples were scanned through $30-90^{\circ}(2 \theta)$ with scanning rate $2^{\circ} \min ^{-1}$. The BET surface areas were measured using nitrogen adsorption isotherms (Micromeritics ASAP 2020). Samples were degassed at $250^{\circ} \mathrm{C}$ for 5 to $6 \mathrm{~h}$ before $\mathrm{N}_{2}$ adsorption.

$\mathrm{CO}$ Temperature programmed desorption (TPD) was performed over $\mathrm{Mo}_{2} \mathrm{C}$ and metal/ $\mathrm{Mo}_{2} \mathrm{C}$ catalysts using a Micromeritics Autochem 2920 II coupled with an Agilent 5975C mass selective detector (MSD). Prior to $\mathrm{CO}$ adsorption, all the samples were carburized in presence of $15 \%$ $\mathrm{CH}_{4} / \mathrm{H}_{2}(50 \mathrm{sccm})$ at $600^{\circ} \mathrm{C}$ (reached at $3^{\circ} \mathrm{C} \mathrm{min}^{-1}$ ) for 4 hours. The sample cell was then purged with Helium at $600^{\circ} \mathrm{C}$ for 30 minutes. The pretreatment was followed by $\mathrm{CO}$ adsorption at RT by flowing a $5 \% \mathrm{CO} / \mathrm{He}(50 \mathrm{sccm})$ mixture for 1 hour. The sample temperature was then linearly increased at $10^{\circ} \mathrm{C} \mathrm{min}^{-1}$ in presence of $\mathrm{He}(30 \mathrm{sccm})$. The $\mathrm{CO}$ desorption response was recorded with the mass selective detector. The quantification of the gases evolved was performed using 
the calibrations developed by injecting known quantities of the gases evolved $\left(\mathrm{CO}\right.$ and $\left.\mathrm{CO}_{2}\right)$. Peak de-convolution was performed using the multiple peak fit tool in OriginPro 8.5.1, and the Peak Analyzer tool was used to estimate the $\%$ contribution of each de-convoluted peak to the total peak area.

In order to observe the effect of the temperature programmed carburization pretreatment over the supported metal nanoparticles (Au and Pt), X-ray absorption measurements were made on the insertion device beam line of the Materials Research Collaborative Access Team (MRCAT) at the Advanced Photon Source, Argonne National Laboratory. Scans at the Au L $\mathrm{keV})$ and the $\mathrm{Pt} \mathrm{L}_{\mathrm{III}}$ edge $(11.564 \mathrm{keV})$ were performed in fluorescence mode for $\mathrm{Au} / \mathrm{Mo}_{2} \mathrm{C}$ and $\mathrm{Pt} / \mathrm{Mo}_{2} \mathrm{C}$ catalysts. The in situ XAS experiments were conducted in quartz fluorescence cell shown in Figure S1, with 1 inch OD tubes connected to welded ball valves with Ultra-Torr fittings (for gas inlet/outlet and sealing) and two Kapton windows. At the mid-point of the reactor tube was a $30^{\circ}$ cone with a $3^{\prime \prime}$ Kapton window. The cone also had a side arm for purging prior to pre-treatments. The special order clam-shell furnace has an angled hole that fits the cone. Samples were pressed into wafers which were kept at a $45^{\circ}$ angle with the X-ray beam inside the in situ reactor, and the fluorescence detector was kept perpendicular to the length of the reactor tube. The scans were collected over the freshly prepared samples (over passivated $\mathrm{Mo}_{2} \mathrm{C}$ ) at RT under air. The catalysts were then subjected to the aforementioned high temperature carburization pretreatment in presence of $15 \% \mathrm{CH}_{4} / \mathrm{H}_{2}$ at $600{ }^{\circ} \mathrm{C}$ and then cooled to $130-140^{\circ} \mathrm{C}$. At this point, the samples were exposed to the WGS reaction mixture $\left(7 \% \mathrm{H}_{2} \mathrm{O}, 8 \%\right.$ $\mathrm{CO}, 7 \% \mathrm{CO}_{2}, 44 \% \mathrm{H}_{2}$ and balance $\mathrm{Ar}$ ). After a period of $1 \mathrm{~h}$, the samples were cooled to RT and were passivated. XAS scans were collected at each stage, viz. after the carburization, during WGS, and after the passivation. XAS spectra were analyzed with the WINXAS 3.1 software 
package. Phase shifts and backscattering amplitudes were obtained from Au foil and Pt foil for $\mathrm{Au}-\mathrm{Au}$ and Pt-Pt respectively. Pt-Mo phase and amplitude functions were calculated using FEFF6. So and $\Delta \sigma^{2}$ were determined by fitting Pt foil and were used for the Pt-Mo scattering pair. Standard procedures based on WINXAS 3.1 software were used to extract the EXAFS data. The coordination parameters were obtained by a least squares fit in $r$-space of the first shell nearest-neighbors, e.g. Pt-Pt and Pt-Mo, from the $k^{2}$-weighted Fourier transform data. X-Ray absorption near edge spectra (XANES) were normalized and obtained using standard background subtraction methods. The XANES were energy calibrated with the known edge position of the first peak in the first derivative of the simultaneously obtained foil spectrum. The edge positions for each of the catalysts were determined from the maximum of the first peak in the first derivative of the XANES.

STEM and EELS analyses were carried out using the dedicated aberration-corrected STEM Hitachi HD-2700C at $200 \mathrm{kV}$ equipped with a modified Gatan Enfina ER spectrometer hosted at the Center for Functional Nanomaterials, Brookhaven National Laboratory. The convergence angle and the ADF collection angles were $28 \mathrm{mrad}$ and 64-341 mrad, respectively. The Enfina spectrometer entrance aperture was set to $3 \mathrm{~mm}$ resulting in an EELS collection angle of 26.7 mrad and an energy resolution of $0.35 \mathrm{eV}$ as measured from the full width at half maximum (FWHM) of the zero-loss peak. The EELS spectra for Mo, Pt and Au were collected at the $\mathrm{M}_{4,5}$ edges. The EELS dwell time was varied between $0.1-0.3$ seconds to avoid beam induced structural changes. The step size for line-scans and mapping was varied between 1-3 $\AA$. The core-loss intensities were extracted by extrapolating the background using a power-law model and subtracting it from the acquired signal. Data processing was carried out using Gatan Digital Micrograph. 


\section{Results}

\subsection{WGS reaction kinetics}

Due to the reversibility of the WGS reaction, the apparent activation energy and the reaction orders with respect to $\mathrm{CO}, \mathrm{H}_{2} \mathrm{O}, \mathrm{H}_{2}$ and $\mathrm{CO}_{2}$ were fitted to a power rate law expression of the form:

$\mathrm{r}=\mathrm{A} \exp \left(-\mathrm{E}_{\text {app }} / \mathrm{RT}\right)(\mathrm{CO})^{\mathrm{a}}\left(\mathrm{CO}_{2}\right)^{\mathrm{b}}\left(\mathrm{H}_{2}\right)^{\mathrm{c}}\left(\mathrm{H}_{2} \mathrm{O}\right)^{\mathrm{d}}(1-\beta)$

Where $\mathrm{r}$ is the overall rate, $\beta=\left(\left(\mathrm{CO}_{2}\right)\left(\mathrm{H}_{2}\right)\right) /\left(\mathrm{K}_{\mathrm{eq}}(\mathrm{CO})\left(\mathrm{H}_{2} \mathrm{O}\right)\right)$ is the approach to equilibrium, $\mathrm{A}$ and $E_{a p p}$ are the apparent pre-exponential factor and apparent activation energy for the forward rate, $\mathrm{a}, \mathrm{b}, \mathrm{c}, \mathrm{d}$ are forward reaction orders, and $\mathrm{K}_{\mathrm{eq}}$ is the equilibrium constant for the WGS reaction. The detailed WGS kinetic data (apparent reaction orders, WGS rates per total moles of metal) are shown in Table S1. All the data were measured at $120^{\circ} \mathrm{C}$. The WGS reaction rates per gram of the catalyst, per total surface area of the catalyst, and the apparent activation energies are reported in Table 1.

Table 1: WGS rate per gram and per unit surface area (BET) at $120^{\circ} \mathrm{C}$ under $7 \% \mathrm{CO}, 8.5 \% \mathrm{CO}_{2}, 22 \% \mathrm{H}_{2} \mathrm{O}, 37.5 \%$ $\mathrm{H}_{2}$, and balance $\mathrm{Ar}$ for Metal/ $\mathrm{Mo}_{2} \mathrm{C}$ catalysts, $\mathrm{Mo}_{2} \mathrm{C}$ and $\mathrm{Cu} / \mathrm{Zn} / \mathrm{Al}_{2} \mathrm{O}_{3}$ catalyst

\begin{tabular}{ccccc}
\hline Catalyst & $\begin{array}{c}\text { WGS Rate at } 120^{\circ} \mathrm{C} / \\
10^{-7} \mathrm{~mol} \mathrm{H}_{2}\left(\mathrm{~g}_{\mathrm{cat}}\right)^{-1} \mathrm{~s}^{-1}\end{array}$ & $\begin{array}{c}\text { WGS Rate at } 120^{\circ} \mathrm{C} / \\
10^{-9} \mathrm{~mol} \mathrm{H}_{2} \mathrm{~m}^{-2} \mathrm{~s}^{-1}\end{array}$ & $\begin{array}{c}\text { Relative } \\
\text { WGS Rate }\end{array}$ & $\begin{array}{c}\mathrm{E}_{\mathrm{a}} / \mathrm{kJ} \mathrm{mol}^{-1} \\
( \pm 3)\end{array}$ \\
\hline $1.5 \% \mathrm{Pt} / \mathrm{Mo}_{2} \mathrm{C}$ & 18 & 29 & 6.3 & 48 \\
$1.5 \% \mathrm{Au} / \mathrm{Mo}_{2} \mathrm{C}$ & 16 & 25 & 5.4 & 44 \\
$1.7 \% \mathrm{Pd} / \mathrm{Mo}_{2} \mathrm{C}$ & 14 & 22 & 4.8 & 63 \\
$1.8 \% \mathrm{Ni} / \mathrm{Mo}_{2} \mathrm{C}$ & 9.5 & 15 & 3.3 & 70 \\
$1.5 \% \mathrm{Cu} / \mathrm{Mo}_{2} \mathrm{C}$ & 5 & 7.7 & 1.6 & 84 \\
$1.9 \% \mathrm{Ag} / \mathrm{Mo}_{2} \mathrm{C}$ & 3 & 4.9 & 1.1 & 87 \\
$\mathrm{Mo}_{2} \mathrm{C}$ & 3 & 4.6 & 1.0 & 90 \\
$\mathrm{Cu} / \mathrm{Zn} / \mathrm{Al}_{2} \mathrm{O}_{3}$ & 2 & 3.4 & 0.74 & 76 \\
\hline
\end{tabular}


a. Relative WGS Rate $=($ WGS Rate per total surface area over Metal/Mo $2 \mathrm{C}) /($ WGS Rate per total surface area over $\mathrm{Mo}_{2} \mathrm{C}$ )

The WGS reaction rate per gram of catalyst over $\mathrm{Mo}_{2} \mathrm{C}$ at $120^{\circ} \mathrm{C}\left(0.3 \mu \mathrm{mol} \mathrm{H}_{2} \mathrm{~g}_{\text {cat }}{ }^{-1} \mathrm{~s}^{-1}\right)$ was 1.5 times higher than that for the commercial $\mathrm{Cu} / \mathrm{ZnO} / \mathrm{Al}_{2} \mathrm{O}_{3}$ catalyst $\left(0.2 \mu \mathrm{mol} \mathrm{H}_{2} \mathrm{~g}_{\mathrm{cat}}{ }^{-1} \mathrm{~s}^{-1}\right)$, measured under the standard gas composition. We note that the BET surface areas of these two catalysts were 65 and $60 \mathrm{~m}^{2} \mathrm{~g}^{-1}$ respectively. The effect of deposition of each metal over $\mathrm{Mo}_{2} \mathrm{C}$ was quantified in terms of the promotion in the WGS rate per unit surface area of catalyst (WGS rates normalized by BET area) measured at $120^{\circ} \mathrm{C}$, i.e. the WGS rates per unit surface area over these supported metal catalysts were compared to that of the $\mathrm{Mo}_{2} \mathrm{C}$ support. The WGS reaction rate per unit surface area of catalyst at $120^{\circ} \mathrm{C}$ varies between $4.6 \times 10^{-9} \mathrm{~mol} \mathrm{H}_{2} \mathrm{~m}^{-2} \mathrm{~s}^{-1}$ for $\mathrm{Mo}_{2} \mathrm{C}$ support and $2.9 \times 10^{-8} \mathrm{~mol} \mathrm{H}_{2} \mathrm{~m}^{-2} \mathrm{~s}^{-1}$ for $1.5 \% \mathrm{Pt} / \mathrm{Mo}_{2} \mathrm{C}$. We define relative WGS rates by normalizing the rate per total surface area over Metal/ $\mathrm{Mo}_{2} \mathrm{C}$ with the rate per total area over unpromoted $\mathrm{Mo}_{2} \mathrm{C}$. Ag $\left(4.9 \times 10^{-9}\right.$ mol $\left.\mathrm{H}_{2} \mathrm{~m}^{-2} \mathrm{~s}^{-1}\right)$ supported on $\mathrm{Mo}_{2} \mathrm{C}$ exhibited WGS rate per unit surface area of catalyst at $120^{\circ} \mathrm{C}$ that was similar to the rate over $\mathrm{Mo}_{2} \mathrm{C}$ ( 1.05 times higher). $\mathrm{Cu}\left(7.7 \times 10^{-9} \mathrm{~mol} \mathrm{H}_{2} \mathrm{~m}^{-2} \mathrm{~s}^{-1}\right)$ showed a small improvement, by a factor of 1.6. Ni promoted the WGS reaction rate per unit surface area over $\mathrm{Mo}_{2} \mathrm{C}$ by a factor of $3.3\left(1.5 \times 10^{-8} \mathrm{~mol} \mathrm{H}_{2} \mathrm{~m}^{-2} \mathrm{~s}^{-1}\right)$; while the extents of promotion were higher for the noble metals. $\mathrm{Pd} / \mathrm{Mo}_{2} \mathrm{C}$ and $\mathrm{Au} / \mathrm{Mo}_{2} \mathrm{C}$ exhibited relative WGS reaction rates of $4.8\left(2.2 \times 10^{-8} \mathrm{~mol} \mathrm{H}_{2} \mathrm{~m}^{-2} \mathrm{~s}^{-1}\right)$ and $5.4\left(2.5 \times 10^{-8} \mathrm{~mol} \mathrm{H}_{2}\right.$ $\left.\mathrm{m}^{-2} \mathrm{~s}^{-1}\right)$ respectively. Deposition of $\mathrm{Pt}$ led to promotion by factor of $6.3\left(2.9 \times 10^{-8} \mathrm{~mol} \mathrm{H}_{2} \mathrm{~m}^{-2} \mathrm{~s}^{-1}\right)$. It should be noted that the extents of promotion in the WGS reaction rates per unit surface area of catalyst are not the highest achievable values. There can be a further promotion achieved by adding higher amounts of rate-promoting metals. The comparison made here should be used to 
assess the efficacy of the admetals when a similar amount (in grams) of each admetal is added to $\mathrm{Mo}_{2} \mathrm{C}$.

The apparent activation energies follow a progressively decreasing trend with increasing WGS rates per unit surface area of the catalyst at $120^{\circ} \mathrm{C}$ (Table 1). Apparent activation energies of $\mathrm{Cu} / \mathrm{Mo}_{2} \mathrm{C}\left(84 \mathrm{~kJ} \mathrm{~mol}^{-1}\right)$ and $\mathrm{Ag} / \mathrm{Mo}_{2} \mathrm{C}\left(87 \mathrm{~kJ} \mathrm{~mol}^{-1}\right)$ were similar to that of the $\mathrm{Mo}_{2} \mathrm{C}$ support (90 $\mathrm{kJ} \mathrm{mol}^{-1}$ ) within error. $\mathrm{Ni} / \mathrm{Mo}_{2} \mathrm{C}$, with a 3.3 times higher WGS rate per unit surface area compared to $\mathrm{Mo}_{2} \mathrm{C}$ at $120^{\circ} \mathrm{C}$, had apparent activation energy of $70 \mathrm{~kJ}$ mol ${ }^{-1}$, whereas $\mathrm{Pd} / \mathrm{Mo}_{2} \mathrm{C}$ with a promotion in the rate per total surface area by a factor of 4.8 , had an apparent activation energy of $63 \mathrm{~kJ} \mathrm{~mol}^{-1}$. Significantly lower apparent activation energies were observed for $\mathrm{Au} / \mathrm{Mo}_{2} \mathrm{C}$ and $\mathrm{Pt} / \mathrm{Mo}_{2} \mathrm{C}\left(44\right.$ and $48 \mathrm{~kJ} \mathrm{~mol}^{-1}$ ). As shown in Figure $\mathrm{S} 2$, the Metal/Mo $/ \mathrm{C}_{2}$ systems exhibit a compensation effect, where a liner relationship between the log of Arrhenius pre-factor and the apparent activation energies was observed. The Arrhenius pre-factors in Figure S2 were estimated from the Arrhenius plots, for which the WGS rates were normalized by the BET surface area of each catalyst. Figure 1 shows these typical Arrhenius plots for all the $\mathrm{Metal} / \mathrm{Mo}_{2} \mathrm{C}$ systems. 


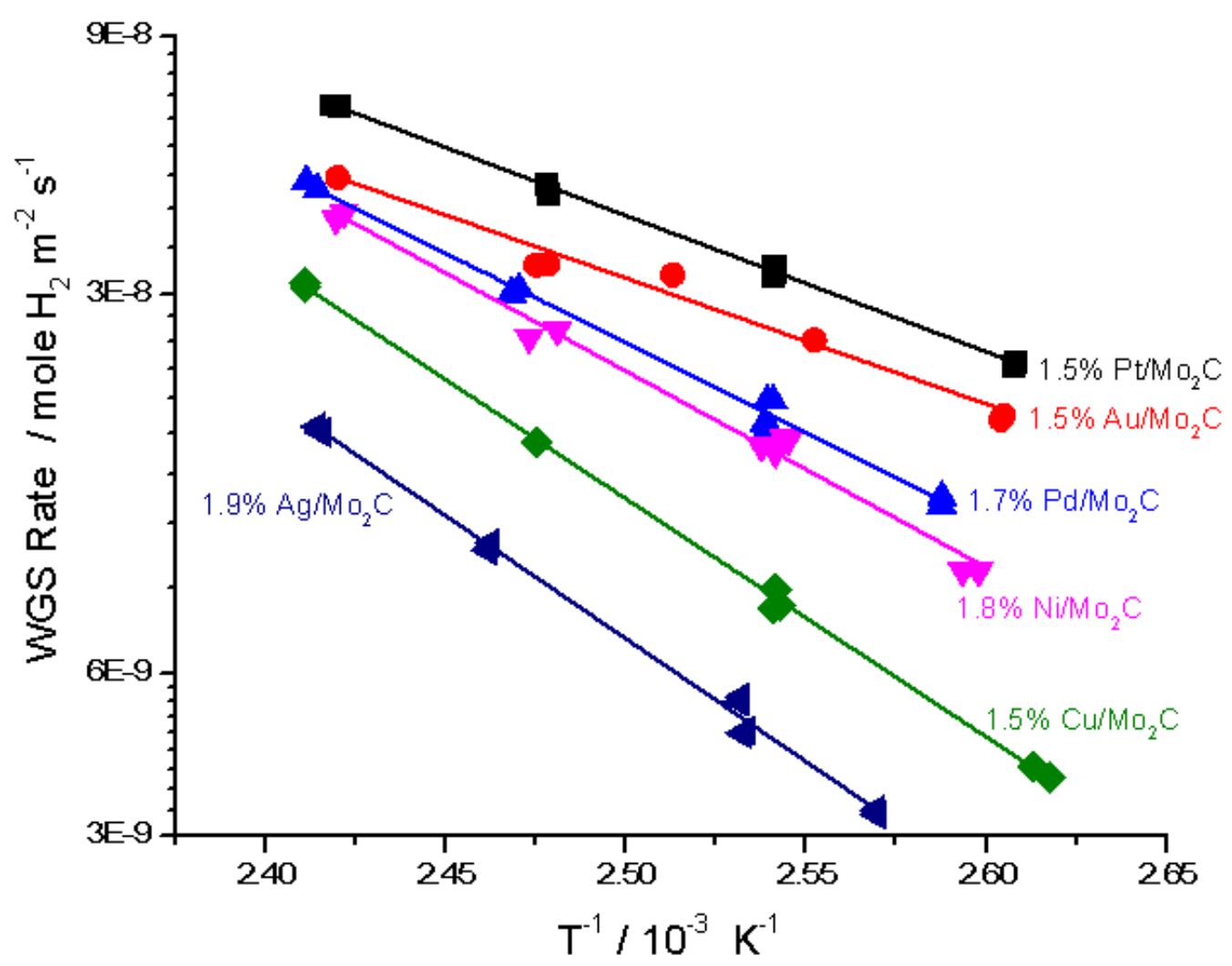

Figure 1: Arrhenius plots of WGS reaction rates for various $\mathrm{Metal} / \mathrm{Mo}_{2} \mathrm{C}$ catalysts

We note that the normalization of the rates by either BET area or total moles of admetals is arbitrary and not expected to produce a fair basis of comparison. The rates are normalized here by the BET area because the surface area of the added metals exposed to the surface could not be selectively measured using chemisorption since $\mathrm{Mo}_{2} \mathrm{C}$ also adsorbs $\mathrm{CO}$ or $\mathrm{H}_{2}$. Also, due to the high atomic number of the $\mathrm{Mo}_{2} \mathrm{C}$ support, estimation of admetal surface area by electron microscopy was not viable, as there were not enough admetal particles clearly imaged to obtain a statistically significant particle size distribution. Nonetheless, it is safe to say that $\mathrm{Ag}$ and $\mathrm{Cu}$ do not promote the WGS rate per total surface area over $\mathrm{Mo}_{2} \mathrm{C}$, while $\mathrm{Ni}, \mathrm{Pd}, \mathrm{Au}$ and $\mathrm{Pt}$ lead to promotions. 
Figure 1 also shows the change in the apparent activation energies from $\mathrm{Ag} / \mathrm{Mo}_{2} \mathrm{C}$ to $\mathrm{Pt} / \mathrm{Mo}_{2} \mathrm{C}$. A comparison of the WGS rates over $\mathrm{Pt} / \mathrm{Mo}_{2} \mathrm{C}$ with various $\mathrm{Pt} / \mathrm{Metal}$ oxide catalysts is shown in Figure S3. Similar to the findings of Schweitzer et al. [7], we observe that the rate per mol Pt over $\mathrm{Pt} / \mathrm{Mo}_{2} \mathrm{C}$ is higher than that of any $\mathrm{Pt} /$ metal oxide catalyst. Compared to $\mathrm{Pt} / \mathrm{CeO}_{2}$, the $\mathrm{Pt} /$ metal oxide catalyst with highest rate per mol Pt, $\mathrm{Pt} / \mathrm{Mo}_{2} \mathrm{C}$ exhibits WGS rate per mol Pt at $120^{\circ} \mathrm{C}$ that is 140 times higher (the WGS rate over $\mathrm{Pt} / \mathrm{CeO}_{2}$ is extrapolated to $120^{\circ} \mathrm{C}$ using the Arrhenius plot). As discussed further in the SI, accurate comparison of the rates is difficult because of our inability to measure metal particle size on the $\mathrm{Mo}_{2} \mathrm{C}$ supports, but even with the most extreme assumptions, the rates per mole of metal are at least an order of magnitude higher for metals supported on the $\mathrm{Mo}_{2} \mathrm{C}$.

Figure $\mathrm{S} 4$ shows the representative plots $\left(\mathrm{Au} / \mathrm{Mo}_{2} \mathrm{C}\right)$ used for determination of apparent reaction orders with respect to $\mathrm{CO}, \mathrm{CO}_{2}, \mathrm{H}_{2} \mathrm{O}$ and $\mathrm{H}_{2}$. Similar plots are used for all the catalysts to measure the apparent reaction orders. Figure 2 shows the apparent $\mathrm{CO}$ orders and the apparent $\mathrm{H}_{2} \mathrm{O}$ orders plotted against the WGS reaction rates per total surface area of catalyst at $120^{\circ} \mathrm{C}$. 


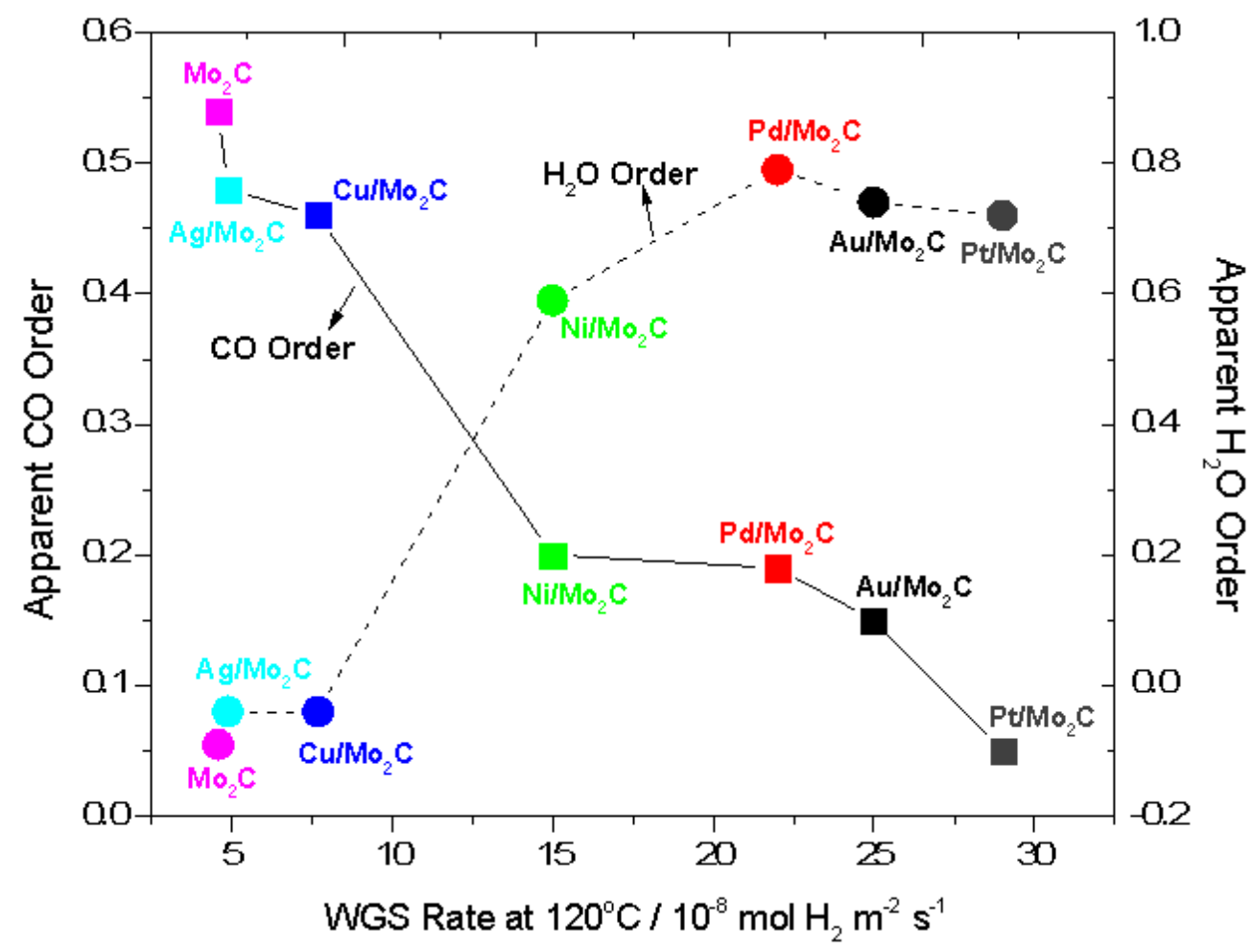

Figure 2: Apparent $\mathrm{CO}$ orders (squares, left y-axis) and apparent $\mathrm{H}_{2} \mathrm{O}$ orders (circles, right y-axis) plotted against the WGS rate per unit surface area (BET) of catalyst at $120^{\circ} \mathrm{C}$ (bottom x-axis) for various Metal/ $\mathrm{Mo}_{2} \mathrm{C}$ catalysts.

The apparent $\mathrm{CO}$ order progressively decreases from $\mathrm{Mo}_{2} \mathrm{C}(0.54)$ to $\mathrm{Pt} / \mathrm{Mo}_{2} \mathrm{C}(0.05)$ with increasing WGS rate. With increasing WGS rate, the apparent $\mathrm{H}_{2} \mathrm{O}$ order undergoes a step change from near zero for $\mathrm{Mo}_{2} \mathrm{C}(-0.09), \mathrm{Cu} / \mathrm{Mo}_{2} \mathrm{C}(-0.04)$ and $\mathrm{Ag} / \mathrm{Mo}_{2} \mathrm{C}(-0.04)$, to 0.6 for $\mathrm{Ni}$, 0.79 for $\mathrm{Pd}, 0.74$ for $\mathrm{Au}$ and 0.76 for Pt supported on $\mathrm{Mo}_{2} \mathrm{C}$. The increase in the WGS rate is clearly accompanied by a significant increase in apparent $\mathrm{H}_{2} \mathrm{O}$ order and decrease in apparent CO order and apparent activation energy.

\subsection{Catalyst Characterization}

The BET surface areas of $\mathrm{Mo}_{2} \mathrm{C}$ and $\mathrm{Metal} / \mathrm{Mo}_{2} \mathrm{C}$ catalysts are listed in Table S1. The analysis was performed on the passivated catalysts. The surface areas for all the catalysts were between 60 and $70 \mathrm{~m}^{2} \mathrm{~g}^{-1}$, indicating that the deposited metals had a negligible effect on the surface area. 
Figure S5 shows the X-ray diffraction patterns for the unsupported $\mathrm{Mo}_{2} \mathrm{C}$ and metal/ $/ \mathrm{Mo}_{2} \mathrm{C}$ catalysts. The diffraction patterns for $\mathrm{Pt} / \mathrm{Mo}_{2} \mathrm{C}, \mathrm{Pd} / \mathrm{Mo}_{2} \mathrm{C}, \mathrm{Ni} / \mathrm{Mo}_{2} \mathrm{C}$ and $\mathrm{Cu} / \mathrm{Mo}_{2} \mathrm{C}$ resembled that of the $\mathrm{Mo}_{2} \mathrm{C}$ support. There were no clearly discernible peaks for the supported metals (for $\mathrm{Pt}$, $\mathrm{Pd}, \mathrm{Ni}$ and $\mathrm{Cu}$ ), suggesting that the size of the admetal particles formed was below the detection limit of X-ray diffraction. However, for $\mathrm{Au} / \mathrm{Mo}_{2} \mathrm{C}$ and $\mathrm{Ag} / \mathrm{Mo}_{2} \mathrm{C}$ (Figure S6), the peaks for $\mathrm{Au}$ $\left(111\right.$ at $\left.38.2^{\circ}\right)$ and $\mathrm{Ag}\left(111\right.$ at $\left.38.3^{\circ}\right)$ were observed for the fresh catalysts. These peaks were not observed from the diffraction patterns for used $\mathrm{Au} / \mathrm{Mo}_{2} \mathrm{C}$ and used $\mathrm{Ag} / \mathrm{Mo}_{2} \mathrm{C}$ catalysts. The implications of these results will be discussed later

Figures 3 and 4 show the normalized intensities of the $\mathrm{CO}$ and $\mathrm{CO}_{2}$ signals recorded in the MSD signal plotted against the temperature during the CO TPD experiments. The details of quantification and de-convolution can be found in Table S5 and Figure S8. In order to highlight the differences caused by the admetals, the $\mathrm{CO}$ and $\mathrm{CO}_{2}$ evolution spectra for unpromoted $\mathrm{Mo}_{2} \mathrm{C}$ were subtracted from the spectra for $\mathrm{Metal} / \mathrm{Mo}_{2} \mathrm{C}$. These 'difference spectra' are shown in Figure S9. Pd, Pt and Au lead to an increase in the intensity of the desorption peak observed around $50^{\circ} \mathrm{C}$. Addition of Ni leads to an increased intensity of the $\mathrm{CO}$ desorption peak near $160^{\circ} \mathrm{C}$. These changes are highlighted by the positive peaks observed in the CO difference spectra. Pd, $\mathrm{Pt}$ and $\mathrm{Au}$ also lead to formation of new peaks in the $\mathrm{CO}_{2}$ evolution spectra above $200^{\circ} \mathrm{C}$. For $\mathrm{Cu}$ and $\mathrm{Ag} / \mathrm{Mo}_{2} \mathrm{C}$, the $\mathrm{CO}$ and $\mathrm{CO}_{2}$ evolution spectra appear very similar to the spectra from unpromoted $\mathrm{Mo}_{2} \mathrm{C}$ in terms of peak shapes and positions. 


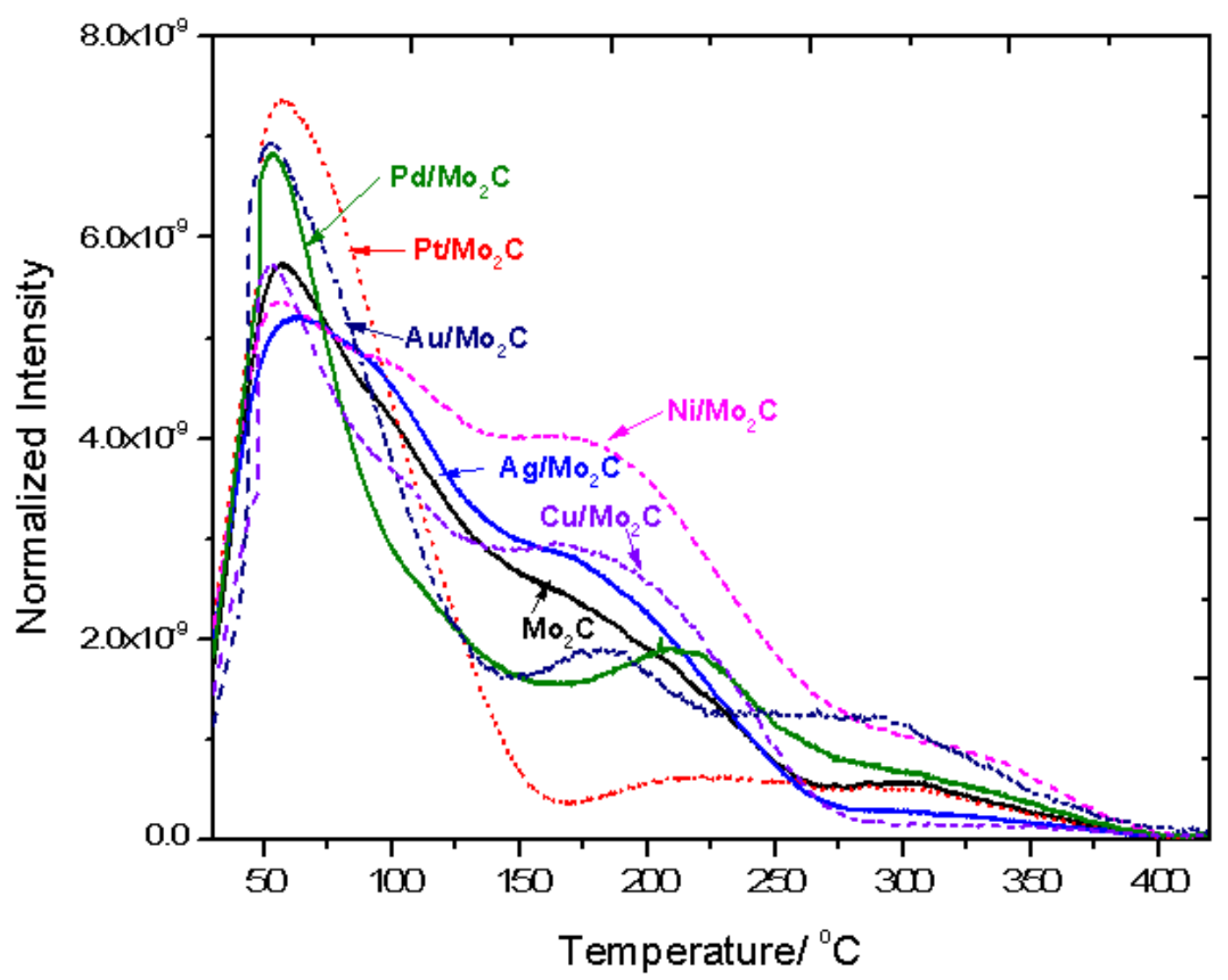

Figure 3: $\mathrm{CO}$ temperature desorption spectra for $\mathrm{Mo}_{2} \mathrm{C}$ and the $\mathrm{Metal} / \mathrm{Mo}_{2} \mathrm{C}$ catalysts. 


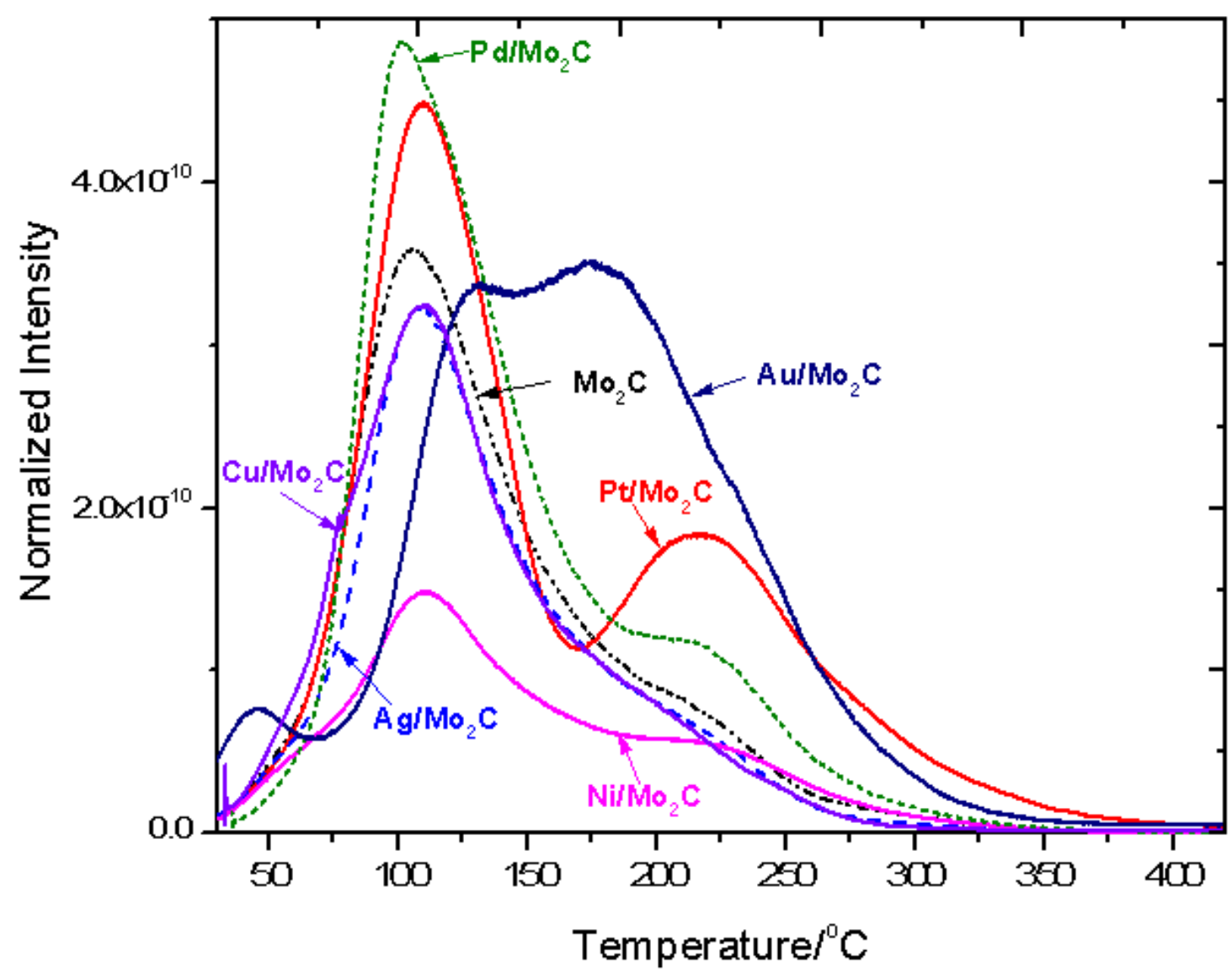

Figure 4: $\mathrm{CO}_{2}$ evolution spectra for $\mathrm{Mo}_{2} \mathrm{C}$ and the $\mathrm{Metal} / \mathrm{Mo}_{2} \mathrm{C}$ catalysts during $\mathrm{CO}$ TPD.

In situ XAS was used to study the chemical states and the coordination environments of the $\mathrm{Mo}_{2} \mathrm{C}$ supported metal nanoparticles $(\mathrm{Au}$ and $\mathrm{Pt}$ ) during different treatments, i.e. carburization, WGS, and passivation. Figure 5 shows the X-ray absorption near edge structure (XANES) spectra for the $\mathrm{Au} / \mathrm{Mo}_{2} \mathrm{C}$ catalyst. The spectrum for the fresh catalyst resembled that of the $\mathrm{Au}$ foil standard, indicating that the Au was metallic in the low temperature reduced catalyst. After the carburization or during WGS, the XANES spectrum did not change significantly. 


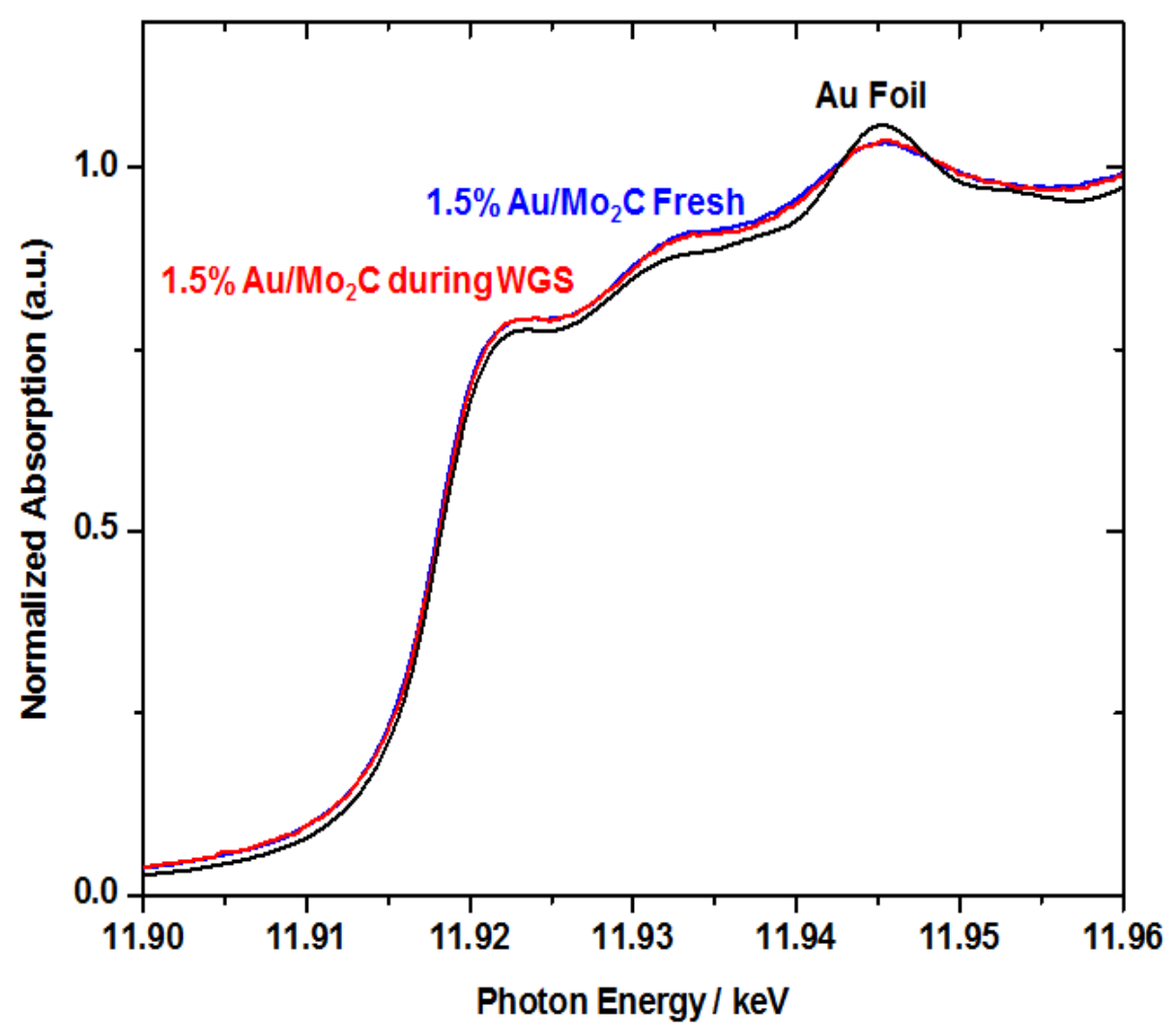

Figure 5: In situ Au L $\mathrm{L}_{\text {III }}$ edge XANES spectrum for 1.5\% Au/Mo $\mathrm{M}_{2} \mathrm{C}$ fresh (red) and 1.5\% $\mathrm{Au} / \mathrm{Mo}_{2} \mathrm{C}$ during WGS (blue).

As shown in Figure 6, after the carburization Pt was reduced, as evidenced by the edge energy of Pt foil $(11.5640 \mathrm{keV})$ and that of $\mathrm{Pt} / \mathrm{Mo}_{2} \mathrm{C}(11.5638 \mathrm{keV})$. However, there is a significant change in the shape of the white line of $\mathrm{Pt} / \mathrm{Mo}_{2} \mathrm{C}$ after carburization and WGS (under helium, at room temperature). Such modifications in the shape of Pt $\mathrm{L}_{\text {III }}$ edge XANES spectra have been attributed to the formation of Pt-Mo bimetallic alloy nanoparticles [10]. 


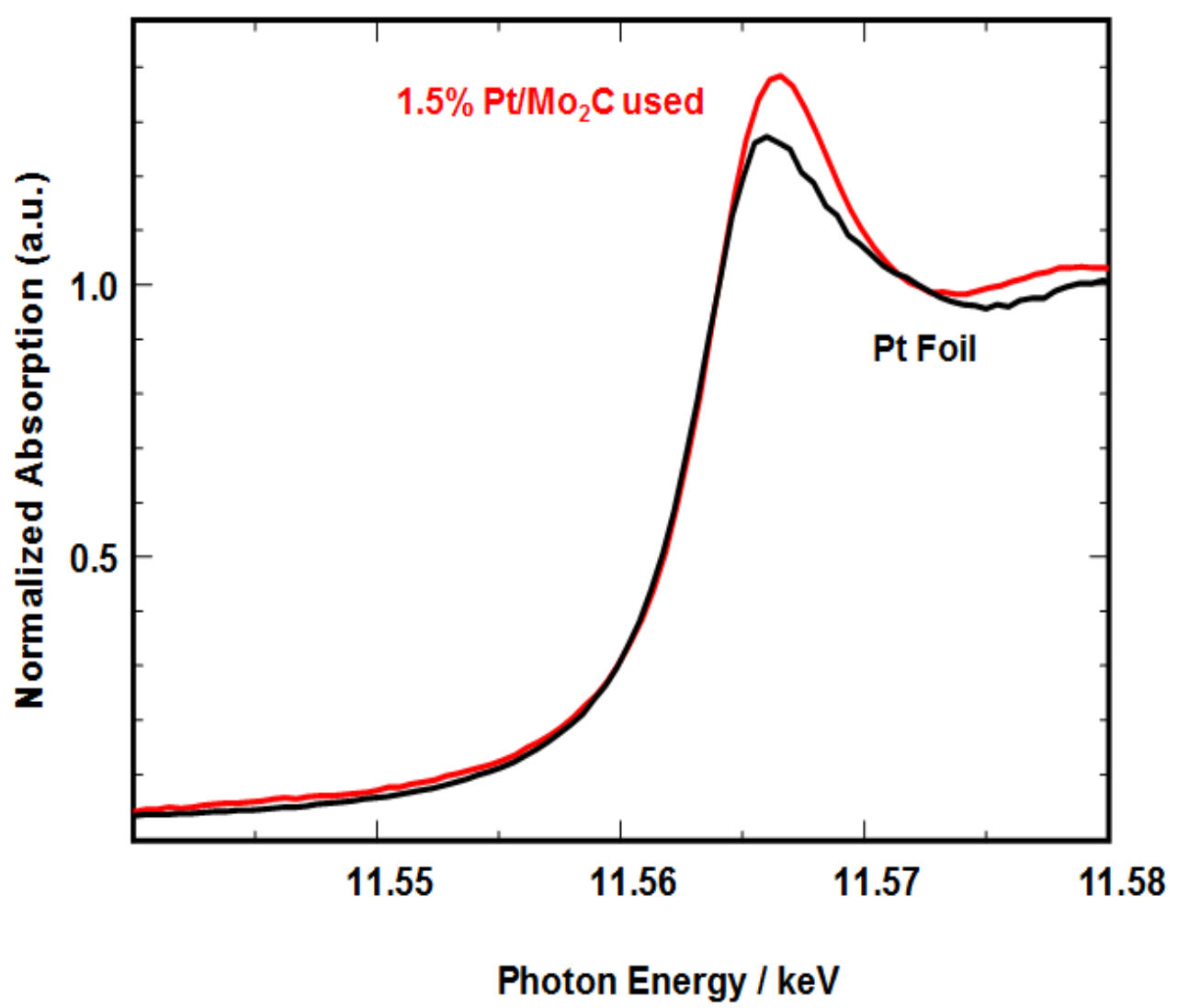

Figure 6: In situ $\mathrm{Pt} \mathrm{L}_{\mathrm{III}}$ edge XANES spectrum for $1.5 \% \mathrm{Pt} / \mathrm{Mo}_{2} \mathrm{C}$ used catalyst. The 'used' catalyst is the $\mathrm{Pt} / \mathrm{Mo}_{2} \mathrm{C}$ that was carburized, exposed to WGS reaction mixture at $130^{\circ} \mathrm{C}$, then passivated at RT.

Figure 7 shows the extended X-ray absorption fine structure (EXAFS) spectra for the $\mathrm{Au} / \mathrm{Mo}_{2} \mathrm{C}$ catalyst, before and after the various treatments. The spectrum for the fresh catalyst is similar to that of the Au foil standard. No Au-O coordination is observed in any sample. As shown in Table S2, the estimated Au-Au coordination number $(\mathrm{CN})$ for the fresh catalyst was 11.4, which was close to 12, the Au-Au $\mathrm{CN}$ for bulk gold. The EXAFS particle size, determined from a previously developed correlation of coordination number with particle size [11], was greater than $9 \mathrm{~nm}$ (EXAFS offers poor precision at this particle size). This indicates that large $\mathrm{Au}$ nanoparticles were formed when the catalyst was prepared by deposition precipitation using the 
passivated $\mathrm{Mo}_{2} \mathrm{C}$ support. During the temperature programmed carburization, no change in the $\mathrm{Au}-\mathrm{Au} \mathrm{CN}$ was observed below $400^{\circ} \mathrm{C}(\mathrm{CN}=10.6)$, but after that point, the $\mathrm{Au}-\mathrm{Au} \mathrm{CN}$ progressively decreased to 8.6 at $600^{\circ} \mathrm{C}$. The catalyst was then cooled to $160^{\circ} \mathrm{C}$ under Helium and then exposed to the WGS reaction mixture, with no significant change in the Au-Au CN.

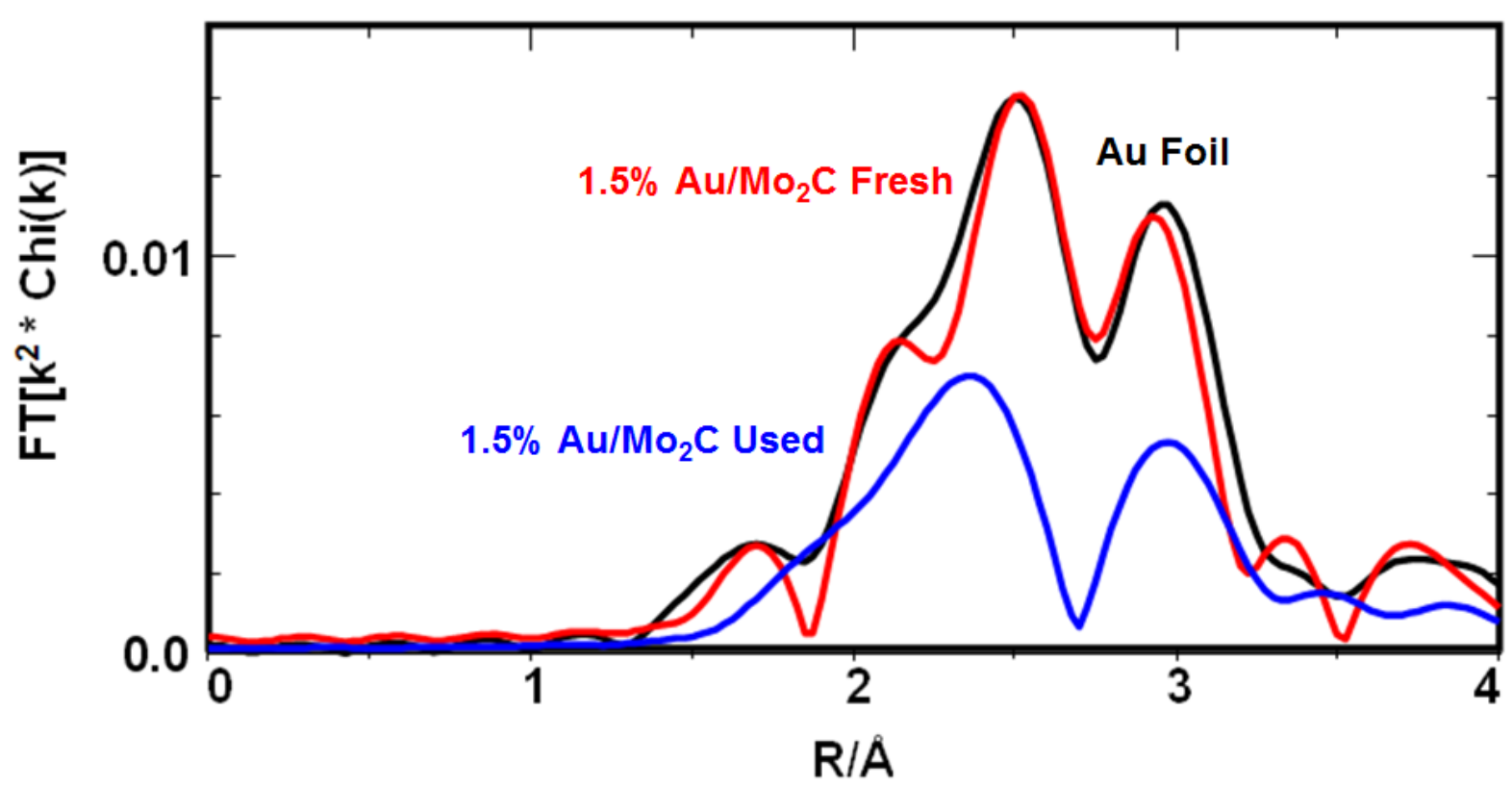

Figure 7: In situ Fourier transforms of the $\mathrm{k}^{2} \mathrm{Au} \mathrm{L}_{\mathrm{III}}$ edge EXAFS spectra for $1.5 \% \mathrm{Au} / \mathrm{Mo}_{2} \mathrm{C}$ fresh (red) and $1.5 \%$ $\mathrm{Au} / \mathrm{Mo}_{2} \mathrm{C}$ used (blue). The 'used' catalyst is the $\mathrm{Au} / \mathrm{Mo}_{2} \mathrm{C}$ that was carburized, exposed to WGS reaction mixture at $130^{\circ} \mathrm{C}$, then passivated at RT.

The estimated average particle size of the Au nano-clusters significantly decreased from greater than $9 \mathrm{~nm}$ to about $3 \mathrm{~nm}$ during this process. After about 1 hour of exposure to the WGS reaction mixture, the catalyst was cooled to RT and was exposed to $1 \% \mathrm{O}_{2} / \mathrm{He}$ for passivation. After the progressive increase in the oxygen concentration, the catalyst was ultimately exposed to air. During the process of passivation, no significant change in the Au-Au CN (and hence, the average $\mathrm{Au}$ particle size) was observed. Thus, the $600^{\circ} \mathrm{C}$ carburization leads to the irreversible re-dispersion of $\mathrm{Au}$ nanoparticles on the surface of the $\mathrm{Mo}_{2} \mathrm{C}$ support. There was no Au-Mo 
coordination observed in the EXAFS (Figure 7), ruling out the formation of alloy nanoparticles. We note that the three peak pattern in the 2-3 $\AA$ region of Figure 7 is caused by multiple scattering from a single (average) Au-Au distance and that the distances and changes in coordination numbers reported in Table S2 come from fits of the data that account for the scattering physics.

The results obtained using Au edge XAS were confirmed with the HAADF-STEM (Figure 8).

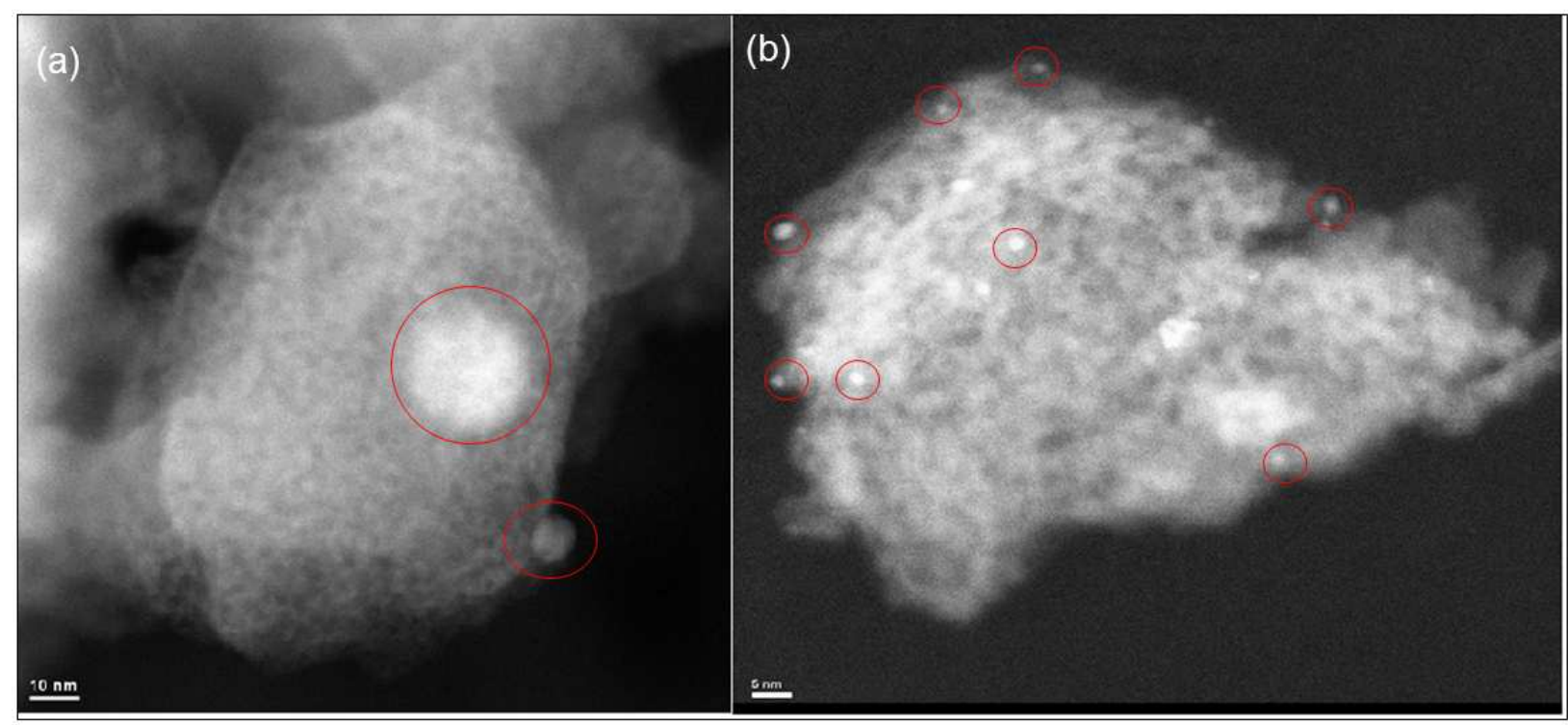

Figure 8: Representative HAADF-STEM micrographs for fresh (a) and used (b) $1.5 \% \mathrm{Au} / \mathrm{Mo}_{2} \mathrm{C}$ catalyst. The gold clusters are denoted with the red circles. These images are in accordance with the Au edge EXAFS results showing the decrease in the avarage Au particle size after the carburization pre-treatment.

Bulk $\mathrm{Mo}_{2} \mathrm{C}$ offers a poor contrast between the metal particles and the support surface, as it a high $\mathrm{Z}$ support. Nonetheless, we were able to image 11 particles over the fresh $\mathrm{Au} / \mathrm{Mo}_{2} \mathrm{C}$ catalyst and the number average particle size was estimated to be $11.5 \pm 6.2 \mathrm{~nm}$. For the used $\mathrm{Au} / \mathrm{Mo}_{2} \mathrm{C}$ catalyst (carburized and passivated), the number average particle size was $2.6 \pm 0.7 \mathrm{~nm}$, based on 
the 39 particles counted. The EELS data shown in Figure 9 confirm that Mo is not present inside the Au particles indicating no formation of Au-Mo alloy nanoparticles.
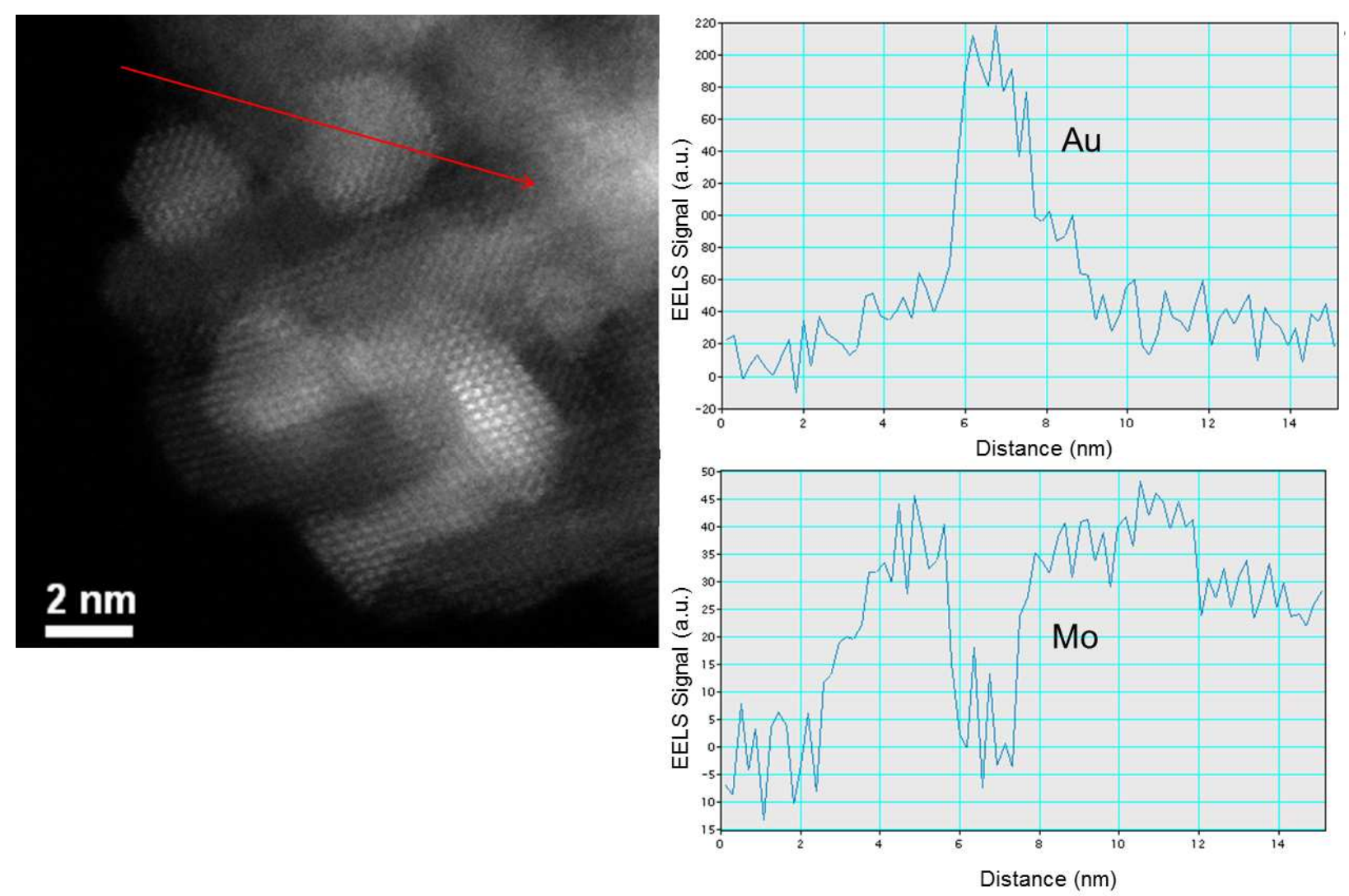

Figure 9: (Left) Representative HAADF-STEM micrograph of the used $1.5 \% \mathrm{Au} / \mathrm{Mo}_{2} \mathrm{C}$ catalyst that is used to assess the compostion of the observed particles The red line represnts the locus of the points at which the EELS scans were collected through the particle. (Right) EELS scans at Au and the Mo edge (intensity vs. distance is plotted). The observed peaks confirm that Au-Mo alloy was not formed.

The state of $\mathrm{Pt}$ on the fresh $\mathrm{Pt} / \mathrm{Mo}_{2} \mathrm{C}$ catalyst was similar to what has been observed on oxide supports such as $\mathrm{Al}_{2} \mathrm{O}_{3}$ when chloroplatinic acid solution is used as a precursor [12]. Pt was in the oxidized state over the fresh catalyst, still bonded to the $\mathrm{Cl}$ counter ions (Table S3). However, the EXAFS data collected after the $600^{\circ} \mathrm{C}$ carburization and under the WGS reaction mixture at $160^{\circ} \mathrm{C}$ showed no Pt-Cl coordination and Pt-Mo coordination was observed instead. 
Mo was included in the coordination sphere to obtain the best fit for the EXAFS data (Figure 10). The estimated Pt-Pt and Pt-Mo average coordination numbers were 6.2 and 4.1 respectively.

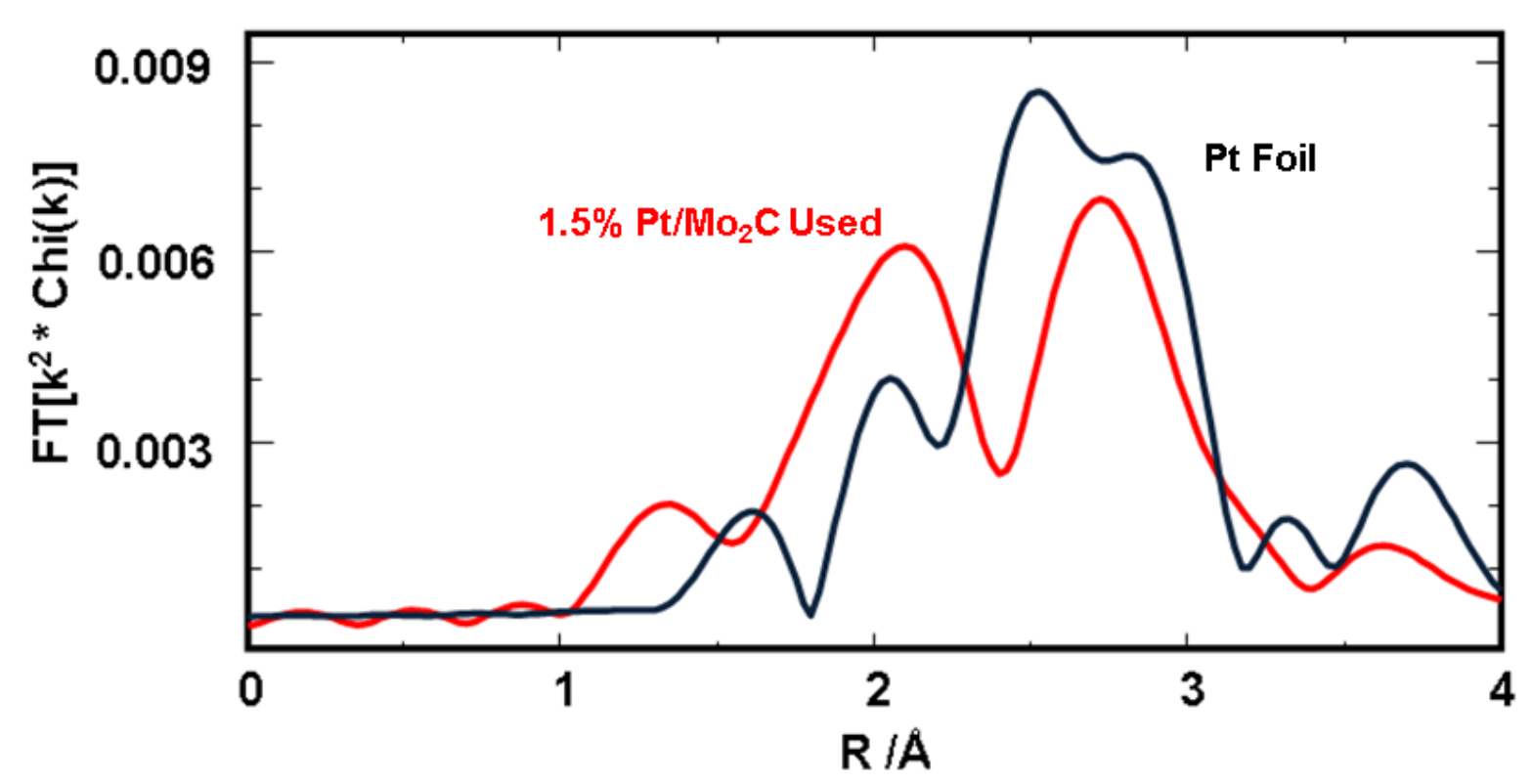

Figure 10: In situ Fourier transforms of the $\mathrm{k}^{2} \mathrm{Pt} \mathrm{L}_{\mathrm{III}}$ edge EXAFS spectra for $1.5 \% \mathrm{Pt} / \mathrm{Mo}_{2} \mathrm{C}$ used (red). The 'used' catalyst is the $\mathrm{Pt} / \mathrm{Mo}_{2} \mathrm{C}$ that was carburized, exposed to WGS reaction mixture at $130^{\circ} \mathrm{C}$, then passivated at $\mathrm{RT}$.

These coordination numbers did not change significantly (Pt-Pt: 5.8, Pt-Mo: 3.7) after the catalyst was passivated at room temperature. Thus, Pt nanoparticles assumed a stable structure after carburization. The observed Pt-Mo coordination suggests the formation of alloy nanoparticles and the absence of Pt-O coordination under WGS confirms that Pt remains metallic. As for Figure 7, the EXAFS patterns in Figure 10 reflect multiple scattering from either Pt neighbors in the case of the foil or Pt and Mo neighbors in the case of the used catalyst. It is the fitting of the scattering physics that leads to the conclusion that both Pt and Mo neighbors are needed to describe the data. The STEM-EELS spectra shown in Figure 11 offer additional 
evidence for the presence of a Pt-Mo alloy. The EELS scans were taken through the particle located at the edge of support crystallite. Signals are observed at both $\mathrm{Pt}$ and Mo edges, suggesting the existence of both the metals in a mixed state.
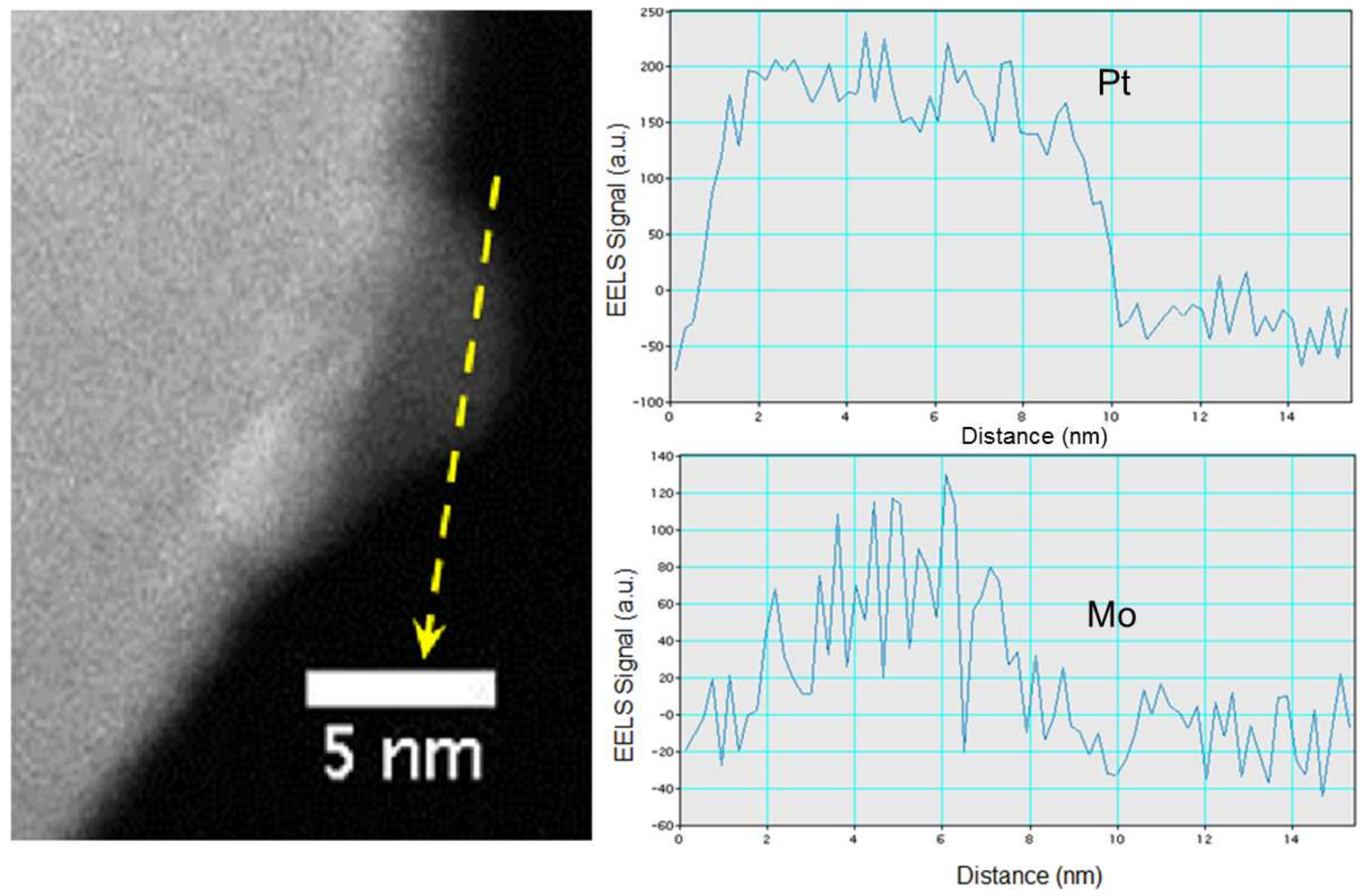

Figure 11: (Left) Representative HAADF-STEM micrograph of the 'used' $1.5 \% \mathrm{Pt} / \mathrm{Mo}_{2} \mathrm{C}$ catalyst used to assess the compostion of the observed particles The yellow line represnts the locus of the points at which the EELS scans were collected through the particle. (Right) EELS scans at Pt and the Mo edge (intensity vs. distance is plotted). The observed peaks confirm the presence of Pt as well as Mo within the particle, suggesting that an alloy was formed after carburization.

\section{Discussion}

\subsection{Implications of WGS reaction kinetics}

The key objective of this work was to synthesize various transition metal catalysts with unsupported $\mathrm{Mo}_{2} \mathrm{C}$ as the support, evaluate their performance towards WGS and gain 
understanding of the role of the rate-promoting admetals. Ag does not lead to a rate promotion; $\mathrm{Cu}$ results in a minor improvement; while $\mathrm{Ni}, \mathrm{Pd}, \mathrm{Au}$ and $\mathrm{Pt}$ significantly promote the WGS rate (per gram, or surface area) compared to that of $\mathrm{Mo}_{2} \mathrm{C}$. The promotion of the WGS rate was also accompanied by a change in kinetic parameters. Since the enhancement in WGS reaction rate and the measured apparent kinetic parameters depend on the type of admetal, we conclude that the kinetically relevant steps occur either on the admetal surface, or at the admetal- $\mathrm{Mo}_{2} \mathrm{C}$ interface.

For the WGS reaction, there are two generally proposed reaction mechanisms, e.g., red-ox and associative mechanisms [13]. The associative mechanism includes the formate and the carboxylate mechanisms [14]. These mechanisms have been developed using a LangmuirHinshelwood model as the basis. For such models, the apparent reaction orders can be mathematically related to the relative coverages, or fractional surface concentrations of adsorbed species involved in the mechanism $[15,16]$. Although absolute surface coverages cannot be estimated from the apparent reaction orders, they do reflect relative changes (increase or decrease) in adsorbate coverage. The lower orders of reaction for the reactants indicate higher coverage of the species generated due to adsorption of reactants. On the unpromoted $\mathrm{Mo}_{2} \mathrm{C}$ surface, the apparent $\mathrm{H}_{2} \mathrm{O}$ order ( - -0.1) is much lower than the order with respect to $\mathrm{CO}(0.54)$. Thus, $\mathrm{CO}$ has the lower coverage relative to water and its dissociation products, which are near surface saturation. The Langmuir-Hinshelwood model also implies that there is a competitive adsorption between adsorbed water and the $\mathrm{CO}$ at the $\mathrm{Mo}_{2} \mathrm{C}$ surface. For the promoting admetals, the $\mathrm{CO}$ reaction order decreases and, thus, surface coverage increases. The corresponding enhancement in rate clearly suggests that the low $\mathrm{CO}$ surface coverage for unpromoted $\mathrm{Mo}_{2} \mathrm{C}$ is rate-limiting and that the $\mathrm{CO}$ surface coverage increases with rate- 
promoting admetals. The changes in the reaction orders suggest further that the catalytic site is the interface between the $\mathrm{Mo}_{2} \mathrm{C}$, which adsorbs and activates $\mathrm{H}_{2} \mathrm{O}$, and metal nanoparticle, which chemisorbs CO.

This model is consistent with the effects of each of the various promoters. For example, addition of Ag did not lead to a significant promotion in the WGS rate and caused no significant changes in the apparent kinetic parameters. It has been previously reported that supported metallic $\mathrm{Ag}$ particles, do not adsorb CO, as observed by transmission infrared spectroscopy [17]. Similarly, for reduced supported $\mathrm{Cu}$ nanoparticles, $\mathrm{CO}$ adsorption has been reported to occur weakly and with uncertain stoichiometry [18]. The addition of $\mathrm{Cu}$ led to a minor rate improvement (1.6 times higher) and similar to Ag, there was no significant change observed in the apparent kinetic parameters. Addition of the rate-promoting metals $\mathrm{Ni}, \mathrm{Pd}, \mathrm{Au}$ and $\mathrm{Pt}$, however, also leads to significant changes in the kinetic parameters. $\mathrm{Ni}, \mathrm{Pd}$ and $\mathrm{Pt}$ are known to strongly chemisorb $\mathrm{CO}$. The correlation between the $\mathrm{CO}$ adsorption energy, increased rate and lower $\mathrm{CO}$ reaction order suggests that $\mathrm{CO}$ adsorbed on the promoter metal nanoparticles participates in the WGS reaction. We emphasize that the kinetic parameters of these systems reflect the local environment around the promoting metal particles because the promoters enhance the rate sufficiently to overwhelm the lower rate still going on at regions on the $\mathrm{Mo}_{2} \mathrm{C}$ surface away from influence of the added metal, even though the fraction of the surface that is promoted is relatively small. Furthermore, since the metals are added to the passivated $\beta-\mathrm{Mo}_{2} \mathrm{C}$ and, as discussed in the Results section, neither the structure of the support nor surface area of the used catalysts changed after metal addition, changes in the chemistry of the support itself, as opposed to the selvedge around the metal particle, can be ruled out. 
One might expect $\mathrm{Au}$ to behave like $\mathrm{Cu}$ and $\mathrm{Ag}$ since $\mathrm{CO}$ is weakly chemisorbed on $\mathrm{Au}$ nanoparticles. However, it has been shown that supported Au nano-clusters that possess sites with coordinative unsaturation such as corners and perimeter sites, chemisorb $\mathrm{CO}$ at these sites $[19,20]$. In addition, the $\mathrm{CO}$ adsorption affinity on Au nanoparticles smaller than about $5 \mathrm{~nm}$ is significantly higher than that on bulk $\mathrm{Au}$ [20]. For $\mathrm{Au} 2.5-3 \mathrm{~nm}$ particle size on $\mathrm{Mo}_{2} \mathrm{C}$, coordinatively unsaturated sites may chemisorb CO leading to higher WGS rates. We note that since it is known small clusters of $\mathrm{Cu}$ also generate coordinatively unsaturated $\mathrm{Cu}$ atoms that can chemisorb CO [21], the lack of such uptake, as indicated by the constant apparent $\mathrm{CO}$ reaction order, on the $\mathrm{Cu} / \mathrm{Mo}_{2} \mathrm{C}$ samples is evidence that small $\mathrm{Cu}$ nanoparticles do not form on $\mathrm{Mo}_{2} \mathrm{C}$ during our pretreatment and reaction protocols.

The near zero $\mathrm{H}_{2} \mathrm{O}$ order for $\mathrm{Mo}_{2} \mathrm{C}$ also suggests that water and hydroxyl intermediates are bonded strongly to the $\mathrm{Mo}_{2} \mathrm{C}$ surface. This interpretation is consistent with the DFT calculations by Liu et al. [22], where dissociation of water was shown to be spontaneous over the clean $\mathrm{Mo}_{2} \mathrm{C}$ (001) surface. The elementary steps $*+\mathrm{H}_{2} \mathrm{O}^{*} \rightarrow \mathrm{H}^{*}+\mathrm{OH}^{*}$ and $*+\mathrm{OH}^{*} \rightarrow \mathrm{O}^{*}+\mathrm{H}^{*}$ were shown to be exothermic for the Mo-terminated and $\mathrm{C}$-terminated $\mathrm{Mo}_{2} \mathrm{C}$ surfaces, implying that water dissociation occurs spontaneously (* denotes the adsorption site). There is additional experimental evidence for spontaneous water dissociation provided by Hwu et al. [23] on a C/Mo (110) single crystal, which shows that water dissociates on the carbide surface to produce $\mathrm{H}_{2}$ even at $75^{\circ} \mathrm{C}$. Furthermore, Tominaga et al. [24] have shown by DFT that water readily dissociates at the $\mathrm{Mo}_{2} \mathrm{C}$ (001) surface. Liu et al. [22] also suggested that the oxygen generated by dissociation of water binds to the $\mathrm{Mo}_{2} \mathrm{C}$ surface strongly, thereby decreasing the number of sites available for the adsorption of other adsorbents. These surface oxygen species, however, where not thought to participate in the catalytic cycle. Nonetheless, these calculations suggest that $\mathrm{CO}$ 
and $\mathrm{H}_{2} \mathrm{O}$ compete for the same sites on the $\mathrm{Mo}_{2} \mathrm{C}$ surface. On $\mathrm{Mo}_{2} \mathrm{C}$, the water coverage is high and the $\mathrm{CO}$ surface coverage is low. For $\mathrm{Mo}_{2} \mathrm{C}$, the $\mathrm{CO}$ surface coverage is rate-limiting.

As shown in Figure 2, for promoted $\mathrm{Mo}_{2} \mathrm{C}$, the $\mathrm{CO}$ surface coverage is higher leading to a higher WGS rate. In addition, there is an increase in the apparent $\mathrm{H}_{2} \mathrm{O}$ order from $\sim 0$ to more than 0.6. This implies a lower effective coverage of water-derived intermediates and also a higher effective $\mathrm{CO}$ coverage at the active site. These results support the hypothesis that the $\mathrm{Metal} / \mathrm{Mo}_{2} \mathrm{C}$ active sites are bi-functional wherein the $\mathrm{CO}$ is chemisorbed on metal nanoparticles and water adsorption and dissociation occurs on $\mathrm{Mo}_{2} \mathrm{C}$ support, at or near the metal/support interface. For oxide-supported WGS catalysts, the metal-support interface is a preferred site for water dissociation as compared to the metal (111) surfaces [25-27]. Similar bi-functional WGS active sites have been previously proposed in the literature $[19,28]$.

As discussed, there is a clear correlation between the increasing reaction rate and the decrease in the apparent activation energy of different rate-promoting admetals. Consequently, as the temperature decreases the relative rate of the Metal/ $\mathrm{Mo}_{2} \mathrm{C}$ catalysts, compared to that of $\mathrm{Mo}_{2} \mathrm{C}$, increases. Bond et al. [29] attributed this Constable-Cremer relationship (compensation effect, Figure S2) to the use of apparent Arrhenius parameters, while Bligaard et al. [30] assigned the explanation for the effect to the changes in the surface coverages of kinetically relevant reaction intermediates, using ammonia synthesis as an example. According to the Temkin formulation [31], the apparent activation energy has a contribution from the barrier for the rate-limiting step (rls) and another contribution from the addition of adsorption enthalpies of kinetically important intermediates weighted by linear functions of their surface coverages $\left(E_{a p p}=E_{\mathrm{rls}}+\Sigma f\left(\theta_{\mathrm{i}}\right) \times\right.$ $\Delta \mathrm{H}_{\text {ads }}^{\mathrm{i}}$ ) For Metal/ $\mathrm{Mo}_{2} \mathrm{C}$ catalysts, the changes in both the $\mathrm{CO}$ and water coverages are marked by the changes in the apparent $\mathrm{CO}$ and $\mathrm{H}_{2} \mathrm{O}$ orders. These changes affect the second term in the 
Temkin equation and are at least partially offsetting. Thus, the data are consistent with a change in the activation energy for the rls with admetal, and the linearity of the Constable-Cremer relationship implies that the rate-limiting step is the same for all catalysts. These findings, together with the changes in the apparent reaction order of $\mathrm{CO}$ with admetal shown in Figure 2, support the conclusion that the beneficial function of the admetal is to increase the CO surface coverage at the active site.

We attempted to measure the diffuse reflectance infrared spectroscopy (DRIFTS) on 1.5\% $\mathrm{Pt} / \mathrm{Mo}_{2} \mathrm{C}$, but no spectra could be obtained for the black samples even at dilution ratios of 80:1 with diamond dust (see SI for details). However, the CO TPD experiments did show subtle differences in the desorption spectra with addition of metals. The evolution of $\mathrm{CO}_{2}$ during $\mathrm{CO}$ TPD over supported catalysts has been reported in the literature before [32]. The possible causes for $\mathrm{CO}_{2}$ formation have been suggested to be $\mathrm{CO}$ oxidation, water-gas shift reaction, or $\mathrm{CO}$ disproportionation. Assuming that $\mathrm{CO}_{2}$ is formed due to one of these surface reactions, it is plausible that the activation barriers for these reactions could be affected by the adsorption strength of $\mathrm{CO}$ and thus the presence of the admetals. The peaks exhibited by $\mathrm{Pt}, \mathrm{Pd}$ and $\mathrm{Au} / \mathrm{Mo}_{2} \mathrm{C}$ in the $\mathrm{CO}$ difference spectra (Figure S9, see SI for detailed description) in the range of 50-80 ${ }^{\circ} \mathrm{C}$ suggest a modification of $\mathrm{Mo}_{2} \mathrm{C}$ support chemistry towards $\mathrm{CO}$ adsorption. More importantly for this discussion, these catalysts also exhibit prominent positive peaks above $200^{\circ} \mathrm{C}$ in the $\mathrm{CO}_{2}$ difference spectra. Assuming that these metals promote the reaction of adsorbed $\mathrm{CO}$ with residual oxygen, these high temperature peaks in the $\mathrm{CO}_{2}$ difference spectra suggest the formation of sites that have different $\mathrm{CO}$ adsorption properties compared to $\mathrm{Mo}_{2} \mathrm{C}$ sites. Even though Ni shows a negative peak in the $\mathrm{CO}_{2}$ difference spectra, the creation of new adsorption sites with addition of $\mathrm{Ni}$ is highlighted by the prominent positive peak observed in the 
CO difference spectrum. Overall, the direct effects of the admetals on the CO TPD spectra are masked by the large $\mathrm{Mo}_{2} \mathrm{C}$ support background. However, the subtle changes highlighted by the difference spectra suggest formation of new sites for $\mathrm{CO}$ activation. We note that the high coverages of $\mathrm{CO}$ in these experiments are not representative of the coverages expected at reaction conditions. As discussed above, those coverages are better represented by the apparent reaction orders in $\mathrm{CO}$.

The kinetic results presented here indicate that the active site in Metal/ $\mathrm{Mo}_{2} \mathrm{C}$ catalysts is bifunctional for the WGS reaction. The comparison of $\mathrm{Pt} / \mathrm{Mo}_{2} \mathrm{C}$ to $\mathrm{Pt} / \mathrm{Metal}$ oxide (made first by Schweitzer et al. [7] and verified by us) highlights the necessity of the rate-promoting admetal as well as the $\mathrm{Mo}_{2} \mathrm{C}$ support in order to observe high WGS reaction rates. Hence, we suggest that the attempts to understand the WGS mechanism theoretically over Metal/ $\mathrm{Mo}_{2} \mathrm{C}$ catalysts (via DFT and kinetic modeling) should include the admetal sites as well the $\mathrm{Mo}_{2} \mathrm{C}$ support sites in a two-site model, wherein the working states of the admetal sites and the support sites are interdependent.

\subsection{Interaction between Admetals and the $\mathrm{Mo}_{2} \mathrm{C}$ Surface}

Au nanoparticles supported on oxide supports such as iron oxide, titanium dioxide and alumina sinter at high reaction temperature [33]. This tendency toward sintering was utilized to vary the average particle size of supported $\mathrm{Au}$ clusters over $\mathrm{Au} / \mathrm{TiO} \mathrm{O}_{2}$ and $\mathrm{Au} / \mathrm{Al}_{2} \mathrm{O}_{3}$ to study the effect of Au particle size on the WGS reaction rate [19]. The particle size of the supported Au clusters has been shown to play an important role in the activity of such catalysts for CO oxidation and WGS reactions $[19,20]$. A driving force for sintering occurs when the cohesive interaction between $\mathrm{Au}$ atoms is stronger than the adhesive interaction between Au and the support. Additionally, at temperatures as high as $600^{\circ} \mathrm{C}$, supported Au clusters can have sufficient mobility to sinter. Such 
behavior was expected for the $\mathrm{Au}$ clusters supported on passivated $\mathrm{Mo}_{2} \mathrm{C}$ during the carburization at $600^{\circ} \mathrm{C}$. However, as demonstrated by TEM and EXAFS, there was a significant decrease in the average Au particle size (from $\sim 9 \mathrm{~nm}$ to $3 \mathrm{~nm}$ ) during carburization. As the temperature increased, the $\mathrm{Au}$ nanoparticles became smaller. This suggests that the adhesive interaction between the $\mathrm{Mo}_{2} \mathrm{C}$ surface and the $\mathrm{Au}$ nanoparticles is stronger than the cohesive interaction between the $\mathrm{Au}$ atoms. The observed decrease in the average particle size of $\mathrm{Au}$ clusters also explains the XRD results for fresh and used (carburized) $\mathrm{Au} / \mathrm{Mo}_{2} \mathrm{C}$. The $\mathrm{Au}$ (111) peak at $38.2^{\circ}$ was observed for the fresh $\mathrm{Au} / \mathrm{Mo}_{2} \mathrm{C}$ catalyst, for which the average Au particle size was $\sim 9 \mathrm{~nm}$, and although this peak overlaps with other peaks from $\mathrm{Mo}_{2} \mathrm{C}$, it is absent in the XRD spectrum of the used catalyst, consistent with a the decrease in the average particle size of $\mathrm{Au}$ crystallites after heating to $600^{\circ} \mathrm{C}$. While we do not have XAS data for the $\mathrm{Ag} / \mathrm{Mo}_{2} \mathrm{C}$ catalyst, the absence of the Ag XRD peak at $38.3^{\circ}$ in the used catalysts suggests that Ag nanoparticles may also disperse on $\mathrm{Mo}_{2} \mathrm{C}$ at high temperature. Although $\mathrm{Ag}$ may be dispersed, it is, nevertheless, a poor WGS promoter.

For the Pt particles, the observed coordination geometry (bond distances and the average coordination numbers) can be satisfied by various morphologies. As proposed by Schweitzer et al.[10], the Pt may form flat raft-like particles, which are only a few layers thick. The EXAFS of such relatively flat particles (compared to the cuboctahedral geometry) is expected to show high Pt-Pt coordination number $(\mathrm{CN})$ and low Pt-Mo CN. Their catalysts had a Pt-Pt CN of about 8 and Pt-Mo $\mathrm{CN}$ near 1.5, Pt-Mo consistent with a Pt monolayer on $\mathrm{Mo}_{2} \mathrm{C}$, i.e., alloy particles were not formed. However, for our catalyst, the Pt-Mo CN was $\sim 4$ and the Pt-Pt coordination number was near 6, suggesting the formation of at least some PtMo alloy, perhaps with a partial enrichment of Mo at the nanoparticle surface to account for the Pt-Pt coordination number being 
higher than the Pt-Mo coordination number. Our HAADF-STEM micrograph with an EELS scan through the metal particle, (at the edge of the support crystallite) confirms that there is Mo as well as Pt present in at least some of the particles. These differences in structure of ours versus the catalyst made by Schweitzer et al. may be due to the differences in preparation methods. For our catalyst, the passivated $\mathrm{Mo}_{2} \mathrm{C}$ was used as a support for incipient wetness impregnation; while the Pt precursor solution was directly contacted with the unpassivated and reduced $\mathrm{Mo}_{2} \mathrm{C}$ by Schweitzer et al. [7]. A more detailed description of the structure of $\mathrm{Pt}$ on $\mathrm{Mo}_{2} \mathrm{C}$ will be reported in a future publication, using 'TEM friendly' carbon nanotubes as a support [34].

In summary, it was observed that the $\mathrm{Au}$ and $\mathrm{Pt}$ (and possibly Ag based on the XRD results) particles interact strongly with the $\mathrm{Mo}_{2} \mathrm{C}$ surface, and the particles do not appear to sinter at temperatures as high as $600^{\circ} \mathrm{C}$. This would make $\mathrm{Mo}_{2} \mathrm{C}$ an ideal support for making thermally robust supported catalysts with these metals.

\section{Conclusions}

The promotion in the WGS rate per unit surface area of catalyst by $\mathrm{Pt}, \mathrm{Au}, \mathrm{Pd}$ and $\mathrm{Ni}$ was accompanied by an increase in the apparent $\mathrm{H}_{2} \mathrm{O}$ order, a decrease in the apparent $\mathrm{CO}$ order, and a decrease in apparent activation energy. This enhancement in the rate and the changes in the kinetic parameters were dependent on the type of admetal and followed a Constable-Cremer (compensation effect) relationship. From the kinetic analysis, it was postulated that the active site for WGS over Metal/ $\mathrm{Mo}_{2} \mathrm{C}$ was the admetal- $\mathrm{Mo}_{2} \mathrm{C}$ interface, where the $\mathrm{Mo}_{2} \mathrm{C}$ adsorbs and activates water, while the metal nanoparticle increases the $\mathrm{CO}$ surface coverage at the active site. In addition, the Constable-Cremer relationship implies that for all catalysts adsorbed $\mathrm{CO}$ is the rate limiting reagent. In Situ XAS and High Resolution STEM-EELS spectra indicated a strong interaction between supported $\mathrm{Au}$ and $\mathrm{Pt}-\mathrm{Mo}$ nanoparticles and the $\mathrm{Mo}_{2} \mathrm{C}$ support leading to 
thermally robust supported metal catalysts. Finally, these results suggest to theoretical modeling (via DFT or microkinetic modeling) of the WGS reaction mechanism over Metal/ $\mathrm{Mo}_{2} \mathrm{C}$ catalysts should include a two-site model with admetal sites as well as $\mathrm{Mo}_{2} \mathrm{C}$ support sites. 


\section{Acknowledgments}

Support for this research was provided by the U.S. Department of Energy, Office of Basic Energy Sciences, through the Catalysis Science Grant No. DE-FG02-03ER15466. Use of the Advanced Photon Source is supported by the U.S. Department of Energy, Office of Science, and Office of Basic Energy Sciences, under Contract DE-AC02-06CH11357. MRCAT operations are supported by the Department of Energy and the MRCAT member institutions. Scanning transmission electron microscopy was carried out at the Center for Functional Nanomaterials, Brookhaven National Laboratory, which is supported by the U.S. Department of Energy, Office of Basic Energy Sciences, under Contract No. DE-AC02- 98CH10886. 


\section{References}

[1] J.H. Sinfelt, D.J.C. Yates, Effect of Carbiding on the Hydrogenolysis Activity of Molybdenum, Nature. 229 (1971) 27-28.

[2] R. Kojima, K. Aika, Molybdenum nitride and carbide catalysts for ammonia synthesis, Appl. Catal. Gen. 219 (2001) 141-147.

[3] H.-G. Kim, K.H. Lee, J.S. Lee, Carbon monoxide hydrogenation over molybdenum carbide catalysts, Res. Chem. Intermed. 26 (2000) 427-443.

[4] J.B. Claridge, A.P.E. York, A.J. Brungs, C. Marquez-Alvarez, J. Sloan, S.C. Tsang, M.L.H. Green, New Catalysts for the Conversion of Methane to Synthesis Gas: Molybdenum and Tungsten Carbide, J. Catal. 180 (1998) 85-100.

[5] B. Dhandapani, T. St. Clair, S.T. Oyama, Simultaneous hydrodesulfurization, hydrodeoxygenation, and hydrogenation with molybdenum carbide, Appl. Catal. Gen. 168 (1998) 219-228.

[6] J. Patt, D.J. Moon, C. Phillips, L. Thompson, Molybdenum carbide catalysts for water-gas shift, Catal. Lett. 65 (2000) 193-195.

[7] N.M. Schweitzer, J.A. Schaidle, O.K. Ezekoye, X. Pan, S. Linic, L.T. Thompson, High Activity Carbide Supported Catalysts for Water Gas Shift, J. Am. Chem. Soc. 133 (2011) $2378-2381$.

[8] L. Bollmann, J.L. Ratts, A.M. Joshi, W.D. Williams, J. Pazmino, Y.V. Joshi, J.T. Miller, A.J. Kropf, W.N. Delgass, F.H. Ribeiro, Effect of Zn addition on the water-gas shift reaction over supported palladium catalysts, J. Catal. 257 (2008) 43-54. 
[9] N.A. Koryabkina, A.A. Phatak, W.F. Ruettinger, R.J. Farrauto, F.H. Ribeiro, Determination of kinetic parameters for the water-gas shift reaction on copper catalysts under realistic conditions for fuel cell applications, J. Catal. 217 (2003) 233-239.

[10] P.J. Dietrich, R.J. Lobo-Lapidus, T. Wu, A. Sumer, M.C. Akatay, B.R. Fingland, N. Guo, J.A. Dumesic, C.L. Marshall, E. Stach, J. Jellinek, W.N. Delgass, F.H. Ribeiro, J.T. Miller, Aqueous Phase Glycerol Reforming by PtMo Bimetallic Nano-Particle Catalyst: Product Selectivity and Structural Characterization, Top. Catal. 55 (2012) 53-69.

[11] J.T. Miller, A.J. Kropf, Y. Zha, J.R. Regalbuto, L. Delannoy, C. Louis, E. Bus, J.A. van Bokhoven, The effect of gold particle size on AuAu bond length and reactivity toward oxygen in supported catalysts, J. Catal. 240 (2006) 222-234.

[12] B. Shelimov, J.-F. Lambert, M. Che, B. Didillon, Initial Steps of the Alumina-Supported Platinum Catalyst Preparation: A Molecular Study by 195Pt NMR, UV-Visible, EXAFS, and Raman Spectroscopy, J. Catal. 185 (1999) 462-478. doi:10.1006/jcat.1999.2527.

[13] C. Ratnasamy, J.P. Wagner, Water Gas Shift Catalysis, Catal. Rev. 51 (2009) 325-440.

[14] L.C. Grabow, A.A. Gokhale, S.T. Evans, J.A. Dumesic, M. Mavrikakis, Mechanism of the Water Gas Shift Reaction on Pt: First Principles, Experiments, and Microkinetic Modeling, J. Phys. Chem. C. 112 (2008) 4608-4617.

[15] I. Chorkendorff, J.W. Niemantsverdriet, Concepts of Modern Catalysis and Kinetics, John Wiley \& Sons, 2006.

[16] C.V. Ovesen, P. Stoltze, J.K. Nørskov, C.T. Campbell, A kinetic model of the water gas shift reaction, J. Catal. 134 (1992) 445-468.

[17] G.W. Keulks, A. Ravi, Infrared spectroscopic study of carbon monoxide adsorption on hydrogen and oxygen treated silver surfaces, J. Phys. Chem. 74 (1970) 783-786. 
[18] A. Dandekar, M.A. Vannice, Determination of the Dispersion and Surface Oxidation States of Supported Cu Catalysts, J. Catal. 178 (1998) 621-639.

[19] M. Shekhar, J. Wang, W.-S. Lee, W.D. Williams, S.M. Kim, E.A. Stach, J.T. Miller, W.N. Delgass, F.H. Ribeiro, Size and Support Effects for the Water-Gas Shift Catalysis over Gold Nanoparticles Supported on Model $\mathrm{Al}_{2} \mathrm{O}$ and $\mathrm{TiO}_{2}$, J. Am. Chem. Soc. 134 (2012) $4700-4708$.

[20] N. Lopez, T.V.W. Janssens, B.S. Clausen, Y. Xu, M. Mavrikakis, T. Bligaard, J.K. Nørskov, On the origin of the catalytic activity of gold nanoparticles for low-temperature CO oxidation, J. Catal. 223 (2004) 232-235.

[21] K. Mudiyanselage, F. Xu, F.M. Hoffmann, J. Hrbek, I. Waluyo, J.A. Boscoboinik, D.J. Stacchiola, Adsorbate-driven morphological changes on $\mathrm{Cu}(111)$ nano-pits, Phys. Chem. Chem. Phys. 17 (2015) 3032-3038.

[22] P. Liu, J.A. Rodriguez, Water-Gas-Shift Reaction on Molybdenum Carbide Surfaces: Essential Role of the Oxycarbide, J. Phys. Chem. B. 110 (2006) 19418-19425.

[23] H.H. Hwu, J.G. Chen, Reactions of methanol and water over carbide-modified Mo(110), Surf. Sci. 536 (2003) 75-87.

[24] H. Tominaga, M. Nagai, Density Functional Theory of Water-Gas Shift Reaction on Molybdenum Carbide, J. Phys. Chem. B. 109 (2005) 20415-20423.

[25] A.B. Vidal, P. Liu, Density functional study of water-gas shift reaction on $\mathrm{M}_{3} \mathrm{O}_{3 x} / \mathrm{Cu}(111)$, Phys. Chem. Chem. Phys. 14 (2012) 16626.

[26] J.A. Rodriguez, S. Ma, P. Liu, J. Hrbek, J. Evans, M. Pérez, Activity of $\mathrm{CeO}_{\mathrm{x}}$ and $\mathrm{TiO}_{\mathrm{x}}$ Nanoparticles Grown on Au(111) in the Water-Gas Shift Reaction, Science. 318 (2007) $1757-1760$. 
[27] S. Aranifard, S.C. Ammal, A. Heyden, On the importance of metal-oxide interface sites for the water-gas shift reaction over Pt/CeO $\mathrm{Ce}_{2}$ catalysts, J. Catal. 309 (2014) 314-324.

[28] K.G. Azzam, I.V. Babich, K. Seshan, L. Lefferts, Bifunctional catalysts for single-stage water-gas shift reaction in fuel cell applications.: Part 1. Effect of the support on the reaction sequence, J. Catal. 251 (2007) 153-162.

[29] G.C. Bond, M.A. Keane, H. Kral, J.A. Lercher, Compensation Phenomena in Heterogeneous Catalysis: General Principles and a Possible Explanation, Catal. Rev. 42 (2000) 323-383.

[30] T. Bligaard, K. Honkala, A. Logadottir, J.K. Nørskov, S. Dahl, C.J.H. Jacobsen, On the Compensation Effect in Heterogeneous Catalysis, J. Phys. Chem. B. 107 (2003) 93259331.

[31] M. Temkin, Relation between the apparent and the true activation energy of heterogeneous reactions, Acta Physicochem. URSS 2 (1935) 313-316.

[32] J.L. Falconer, J.A. Schwarz, Temperature-Programmed Desorption and Reaction: Applications to Supported Catalysts, Catal. Rev. 25 (1983) 141-227.

[33] R. Zanella, C. Louis, Influence of the conditions of thermal treatments and of storage on the size of the gold particles in $\mathrm{Au} / \mathrm{TiO}_{2}$ samples, Catal. Today. 107-108 (2005) 768-777.

[34] K.D. Sabnis, M.C. Akatay, Y. Cui, F.G. Sollberger, J.T. Miller, W.N. Delgass, F.H. Ribeiro, Probing the Active Sites for Water-Gas Shift over Pt-modified Molybdenum Carbide using Multi-Walled Carbon Nanotubes, Submitted. 
Graphical Abstract (for review)

\section{Graphical Abstract}
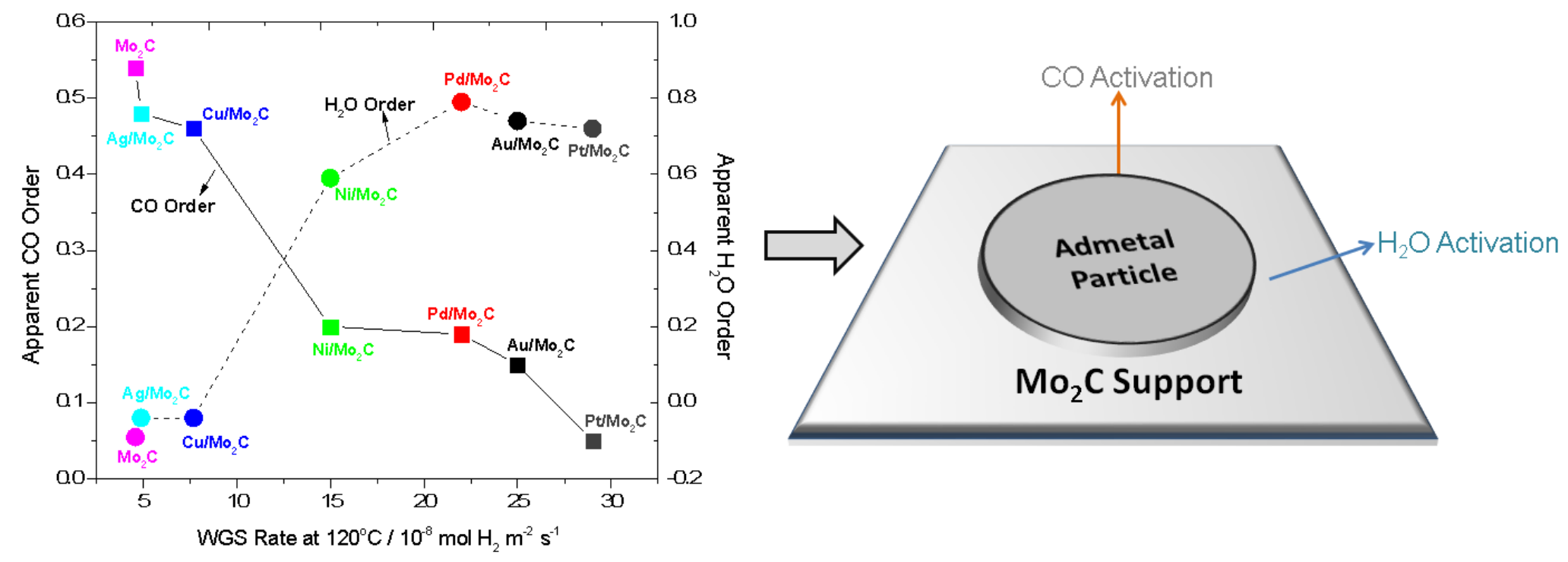

WGS Rate at $120^{\circ} \mathrm{C} / 10^{-8} \mathrm{~mol} \mathrm{H}_{2} \mathrm{~m}^{-2} \mathrm{~s}^{-1}$ 